\title{
Bożena Płonka-Syroka
}

Zakład Humanistycznych Nauk Wydziału Farmaceutycznego

Uniwersytetu Medycznego im. Piastów Śląskich we Wrocławiu

\section{Niemiecka medycyna niematerialistyczna 1797-1848 w świetle historiografii $\mathrm{z}$ lat 1811-2014}

Zarys treści: Niemiecka medycyna romantyczna z lat 1797-1848 jest obecnie przedmiotem rozwiniętych badań prowadzonych zgodnie z zasadami metodologicznymi właściwymi dla nauk humanistycznych: historii, socjologii, antropologii kulturowej i antropologii medycyny klinicznej. Tego rodzaju standard interpretacyjny pojawił się w poświęconych tej epoce pracach w latach 70 . XX w., a od lat 90. do chwili obecnej jest standardem dominującym. Celem niniejszego artykułu jest przedstawienie wcześniejszych sposobów historiograficznego opisu tej epoki i ukazanie, w jaki sposób dominująca dziś perspektywa kształtowała się w sporach teoretycznych toczonych przez badaczy tej epoki w XIX i XX w. Artykuł zawiera omówienie najważniejszych ujęć teoretycznych występujących w historiografii niemieckiej medycyny romantycznej (ujęcie eklektyczne, filozoficzne, jednobiegunowe, dwubiegunowe, trójbiegunowe i wielobiegunowe) oraz przedstawia charakterystyczne dla każdego $\mathrm{z}$ tych ujęć prace powstałe do połowy XX w. Piśmiennictwo późniejsze, a także prace $\mathrm{z}$ lat 1900-1945, niezwiązane wyraźniej z żadnym z ujęć teoretycznych, zostało przywołane w cytowanych w artykule monografiach, będących wynikiem moich badań nad historiografią medycyny niemieckiej.

The outline content: German romantic medicine from 1797-1848 has for some time been subjected to thorough scholarly investigations involving the employment of methodologies from different humanistic disciplines: history, sociology, cultural anthropology and the anthropology of clinical medicine. The topic was first dealt with in such a way in works published in the 1970s. From the 1990s onwards, such a versatile approach has been commonly adopted by scholars. The purpose of the article is to show how historiography, beginning in 1811, described the phenomenon in question and how today's view of this has emerged from theoretical debates held by students in the nineteenth and twentieth centuries. This article discusses the most important theoretical perspectives from which German historiography has approached romantic medicine (eclectic, philosophical, unipolar, bipolar, triple-polar and multi-polar). It contains references to works published until the mid-twentieth century and representing each of the perspectives. Works that appeared later, as well as those published in 1900-1945 but linked to none of the theoretical perspectives indicated above, are mentioned in the monographs, referenced in the article, that are the result of my research into the historiography of German medicine.

Słowa kluczowe: niemiecka medycyna romantyczna, standard romantyczny w medycynie, historiografia niemieckiej medycyny romantycznej

Key words: German romantic medicine, romantic standard in medicine, the historiography of German medicine 
Niemiecka medycyna niematerialistyczna $\mathrm{z}$ lat $1797-1848^{1}$, określana także $\mathrm{w}$ historiografii mianem niemieckiej medycyny romantycznej, była zjawiskiem odosobnionym w ogólnym standardzie metodologicznym głównego nurtu modernizacyjnego europejskiego przyrodoznawstwa, którego podstawy zaczęly się tworzyć od początku XVIII w. pod wpływem filozofii oświecenia². Około 1750 r. nurt ten, określany w historiografii europejskiej mianem tzw. medycznego oświecenia (Medical Enlightenment) ${ }^{3}$, był już dobrze ukształtowany pod względem teoretycznym

${ }^{1}$ Badania nad standardem niemieckiej historiografii medycyny $\mathrm{z}$ lat 1811-2013 dotyczącej historii rodzimej medycyny $\mathrm{z}$ lat 1797-1848 prowadziłam w latach 1992-2013 w ramach programów badawczych finansowanych przez Deutscher Akademischer Austausch Dienst, Komitet Badań Naukowych oraz stypendium naukowe Unii Europejskiej (Program Kapitał Ludzki). Wyniki tych badań opublikowałam w monografiach: Medycyna niemiecka nurtu niematerialistycznego 1797-1848 i polska recepcja jej teorii i doktryn w dziewiętnastym stuleciu, Warszawa 1999 (wyd. 2 rozsz. pt. Niemiecka medycyna romantyczna, Warszawa 2007) oraz Medycyna w historii i kulturze. Studia $z$ antropologii wiedzy, Wrocław 2013 (wyd. 2 rozsz. pt. Medycyna w historii i kulturze, Warszawa 2016), a także w szeregu artykułów. W polskiej historiografii medycyny XIX i XX w. temat niemieckiej medycyny romantycznej nie był podejmowany wcześniej przez innych autorów, zarówno w ujęciu analitycznym, jak i historiograficznym. Nie występowało także wcześniej w polskiej historiografii medycyny samo pojęcie „niemiecka medycyna romantyczna”. Niektóre związane z tym okresem zagadnienia i postacie lekarzy były omawiane w polskich podręcznikach historii medycyny, nie była jednak przedstawiana w polskim piśmiennictwie naukowym całościowa charakterystyka tej epoki w historii niemieckiej medycyny klinicznej. W związku z tym w przypisach erudycyjnych do niniejszego opracowania jestem zmuszona powoływać się - poza piśmiennictwem obcym - wyłącznie na swoje własne prace z zakresu historii i historiografii medycyny klinicznej. Czytelników zainteresowanych szczegółowym omówieniem tej epoki odsyłam do wymienionych wyżej monografii, w których obok moich analiz materiału źródłowego z lat 1797-1848 znajduje się także odniesienie do bardzo obszernego piśmiennictwa obcego, głównie w języku niemieckim, poświęconego historii rodzimej medycyny z końca XVIII i pierwszej połowy XIX w. Problematyka niemieckiej nauki romantycznej jest natomiast obszernie analizowana w polskim piśmiennictwie filozoficznym oraz w pracach germanistów. Rzadko jednakże wspomniane piśmiennictwo podejmuje kwestie związane z medycyną kliniczną. Na uwagę zasługuje tu głównie monografia Leona Miodońskiego pt. Całość jako paradygmat rozumienia świata w myśli niemieckiej przełomu romantycznego. Analiza wybranych problemów, Wrocław 2001, powstała już po opublikowaniu mojej monografii dotyczącej niemieckiej medycyny niematerialistycznej (1999), a także późniejsze artykuły i opracowania zbiorowe pod redakcją prof. Miodońskiego, zawierające odniesienia do związków niemieckiej idealistycznej filozofii przyrody i niemieckiej medycyny klinicznej z pierwszej połowy XIX w.

2 Por. M. Hahn, H.J. Sandkühler, Die Teilung der Vernunft. Philosophie und empirisches Wissen im 18. und 19. Jahrhundert, Köln 1982; P. Chaunu, Cywilizacja wieku Oświecenia, tłum. E. Bąkowska, Warszawa 1993; F. Cohen, Die zweite Erschaffung der Welt. Wie die moderne Naturwissenschaft entstand, Frankfurt-New York 2010; por. też: B. Płonka-Syroka, Medycyna niemiecka nurtu niematerialistycznego..., s. 159-196.

${ }^{3}$ Por. A. Cunningham, R. French, The Medical Enlightenment of the Eighteenth Century, Cambridge 1990; Medicine in the Enlightenment, red. R. Porter, Amsterdam 1995; L.S. King, The Medical World of the Eighteenth Century, Chicago 1958; Medical Theory and Therapeutic Practice in the Eighteenth Century. A Transatlantic Perspective, red. J. Helm, R. Wilson, Stuttgart 2008; Ch. Probst, Der Weg des ärztlichen Erkennens am Krankenbett. Hermann Boerhaave und die Altere Wiener Medizinische Schule (1701-1787), Wiesbaden 1973; E. Lesky, Wien und die Weltmedizin, Wien- 
i praktycznym, i stopniowo wdrażany na wydziałach lekarskich europejskich uniwersytetów. Jego standard, określany mianem standardu klinicznego ${ }^{4}$, opierał się na nowych podstawach fizycznych, których ramy określiła synteza Newtona ${ }^{5}$, oraz na nowych podstawach metodologicznych, które z nich wyprowadzano ${ }^{6}$. Do podstawowych cech nowego standardu medycyny w Europie należały dążenia do profesjonalizacji dyskursu akademickiego ${ }^{7}$, oparcia medycyny na profesjonalnej filozofii i metodologii ${ }^{8}$, porzucenia sporów światopoglądowych wpływających na kierunki modernizacji medycyny ${ }^{9}$, definiowania procesów fizjologicznych i patologicznych $\mathrm{w}$ kategoriach naturalistycznych ${ }^{10}$ oraz akceptacji wnioskowania przyczynowego zamiast dotychczasowych wyjaśnień teleologicznych ${ }^{11}$. Uzasadnieniem wprowadzenia nowego standardu było dążenie do zasadniczej poprawy skuteczności terapii, ogólnej poprawy stanu zdrowia populacji, ograniczenia wielkiej śmiertelności kobiet ${ }^{12}$, dzieci ${ }^{13}$ oraz mężczyzn $\mathrm{z}$ wieku produkcyjnym i poborowym.

-Köln 1974; F.T. Brechka, Gerhard van Swieten and his World 1700-1772, Hague 1970; U. Schäfer, Physikalische Heilmethoden in den Ersten Wiener Medizinische Schule, Baltimore 1967; William Cullen and the Eighteenth Century Medical World, red. A. Doig, Edinburg 1991.

${ }^{4}$ Por. V. Hess, Von der semiotischen zur diagnostischen Medizin. Die Entstehung der klinischen Methode zwischen 1750 und 1850, Husum 1993; por. też: B. Płonka-Syroka, Metodologia Ludwika Flecka w kontekście standardu teoretycznego medycyny klinicznej (1750-1850), w: Ludwik Fleck: tradycje, interpretacje, inspiracje, red. B. Płonka-Syroka, P. Jarnicki, B. Balicki, Wrocław 2015, s. 10-40; taż, Medycyna kliniczna i alternatywna - próba charakterystyki porównawczej, w: Gra możliwości. Studia $z$ historii medycyny i farmacji XIX i XX wieku, red. B. Płonka-Syroka, Wrocław 2011 (Studia Humanistyczne Wydziału Farmaceutycznego Akademii Medycznej we Wrocławiu, 4), s. 23-42.

5 Por. M. Boas-Hall, Promoting Experimental Learning. Experiment and the Royal Society (1660-1727), New York 1991; A. Croce-Birch, The Problem of Method in Newton's Natural Philosophy, w: Nature and Scientific Method, red. D.D. Dahlstrom, Washington 1991, s. 253-270.

${ }^{6}$ Stan medycyny sprzed reformy klinicznej przedstawia Max Stolberg w pracy Therapeutic Pluralism and Conflicting Medical Opinions in the Eighteenth Century. The Patient's View, w: Medical Theory and Therapeutic Practice..., s. 95-112. Dalszy przebieg procesu standaryzowania się terapii w medycynie europejskiej przedstawia Huldrych Koelbing w monografii pt. Die ärztliche Therapie. Grundlage ihrer Geschichte, Darmstadt 1985.

7 Por. C. Huercamp, Der Aufstieg der Ärzte im 19. Jahrhundert. Vom gelehrten Stand zum professionellen Experten. Das Beispiel Preussen, Göttingen 1985.

${ }^{8}$ Por. L.S. King, The Philosophy of Medicine. The Early Eighteenth Century, Cambridge (Mass.)-London 1978.

${ }^{9}$ Por. B. Płonka-Syroka, Koncepcja podmiotowości człowieka wobec podstawowych pojęć medycyny teoretycznej i praktycznej, „Kwartalnik Historii Nauki i Techniki” 43, 1998, nr 2, s. 65-76.

10 Por. taż, Niemiecka medycyna romantyczna... (2007), s. 235.

11 Por. taż, Nowożytny ideał nauki, w: tamże, s. 151; por. też P. Badyna, Bóg i przyroda w XVIII-wiecznym piśmiennictwie przyrodoznawczym jako konstrukt kulturowy, w: Obrazy świata jako konstrukty świata kultury. Analiza historyczno-porównawcza, red. B. Płonka-Syroka, A. Syroka, Wrocław 2012 (Studia z Dziejów Kultury Medycznej, 12), s. 15-34.

12 Śmierć przy porodzie i w połogu była główną przyczyną śmiertelności kobiet w wieku rozrodczym. Śmiertelność okołoporodowa sięgała w XVIII i XIX w. ok. 30\% położnic.

${ }_{13}$ Do siódmego roku życia dożywało mniej niż połowa dzieci, a od 20 do $50 \%$ noworodków w zależności od warstwy społecznej - umierało jeszcze przed osiągnięciem pierwszego roku życia. 
W państwach zachodnioeuropejskich zdecydowano się na zasadnicze reformy szkolnictwa medycznego, mające doprowadzić do wzrostu liczby lekarzy i do ich kształcenia według standardu podporządkowanego potrzebom praktycznym. Stworzono też wówczas pierwsze państwowe systemy medycyny publicznej ${ }^{14}$.

Europejski standard kliniczny głównego nurtu jest określany mianem standardu somatycznego. Określenie to zostało wprowadzone w drugiej połowie XVIII w. przez akceptujących ów standard lekarzy, aby odróżnić podstawy teoretyczno-światopoglądowe, na których się opierali, od filozoficznego materializmu i związanych z nim możliwych implikacji ateistycznych. Medycyna kliniczna nurtu somatycznego nie negowała istnienia Boga ani duchowych aspektów ludzkiej egzystencji, niemniej jednak uznawała za zasadne stworzenie naturalistycznej koncepcji ludzkiego organizmu i zbadanie jego funkcjonowania w otaczającym środowisku. Przyczyny chorób miały w tej koncepcji charakter naturalny, wynikały z wpływów środowiska na organizm, który nie był w stanie przed nimi się obronić. Standard somatyczny stał się więc podstawą tworzenia nowoczesnej koncepcji profilaktyki, zmierzającej do rozpoznania szkodliwych wpływów otoczenia na organizm i ograniczenia ich oddziaływań. Profilaktyka opierała się na popularyzacji podstaw higieny, tworzeniu racjonalnych norm odżywania, szczepieniach ochronnych, izolacji chorych w wypadku wystąpienia epidemii. Wszystkie te działania opierały się na przekonaniu, że występowanie chorób jest ściśle związane z postępowaniem człowieka, $\mathrm{z}$ jego stylem życia i warunkami materialnymi jego egzystencji. W związku z tym działania zapobiegające wystąpieniu chorób uznawano za tak samo ważne zadanie medycyny jak ich leczenie. Szczegółowa charakterystyka europejskiego standardu klinicznego głównego nurtu wykracza poza ramy niniejszej pracy, przedstawiłam ją obszernie we wcześniejszych publikacjach ${ }^{15}$. Do reprezentatywnych przedstawicieli tego standardu w niemieckiej medycynie klinicznej końca XVIII i pierwszej połowy XIX w. należeli Christoph Wilhelm Hufeland ${ }^{16}$, Friedrich Hildebrandt ${ }^{17}$,

${ }^{14}$ Por. B. Płonka-Syroka, Medycyna w historii i kulturze. Studia..., s. 276-436; taż, System policji lekarskiej Johanna Petera Franka jako przykład realizacji oświeceniowej idei prawa do zdrowia, w: Czystość i brud. Higiena nowożytna (XV-XVIII w.), red. W. Korpalska, W. Ślusarczyk, Bydgoszcz 2015, s. 307-328.

${ }_{15}$ Por. taż, Program somatyczny, w: taż, Niemiecka medycyna romantyczna... (2007), s. 234-239; taż, Krytyka programu somatycznego, w: tamże, s. 239-240; taż, Wybrane problemy medyczne w interpretacjach zwolenników programu somatycznego, w: tamże, s. 263-297.

16 Por. Ch.W. Hufeland, Ideen über Pathogenie und Einfluss, Entstehung und Form der Krankheit als Einleitung zu pathologischen Vorlesungen, Jena 1795; tenże, Die Kunst das menschliche Leben zu verlängern, Jena 1797; tenże, Pathologie. t. 1: Pathogenie, Jena 1799; tenże, Ueber die Natur, Erkenntnissmittel und Heilart der Skrofelnkrankheit, Wien 1810; tenże, Geschichte der Gesundheit nebst einer psychischen Charakteristik des jetzigen Zeitalters, Berlin 1812; tenże, Lehrbuch der allgemeinen Heilkunde, Jena 1818; tenże, Enchiridion medicum oder Anleitung zur medizinischen Praxis, Berlin 1836.

17 Por. F. Hildebrandt, Über die Arzneykunde, Erlangen 1795; tenże, Die Physiologie, Erlangen 1796; tenże, Grundriss der allgemeinen Krankheitslehre, Nürnberg-Altdorf 1796; tenże, Lehrbuch der Physiologie, Erlangen 1816. 
Philipp Franz von Walther ${ }^{18}$, Melchior Adam Weikard ${ }^{19}$, Ludwig Formey ${ }^{20}$, Adalbert Friedrich Marcus ${ }^{21}$, Joseph August Schultes ${ }^{22}$, Christian Friedrich Nasse $^{23}$, Andreas Röschlaub ${ }^{24}$, Ernst Horn ${ }^{25}$, Johann Israel Stieglitz ${ }^{26}$, Johan Christoph Hoffbauer ${ }^{27}$, Carl August Ferdinand Kluge ${ }^{28}$, Johan Nepomuk von Ringseis ${ }^{29}$, Christian Heinrich Pfaff ${ }^{30}$ i Karl Asmund Rudolphi ${ }^{31}$. Wspólną cechą ich koncepcji medycyny było jej zakorzenienie w doświadczeniu i obserwacji, akceptacja relatywistycznego charakteru poznania naukowego w medycynie, zależnego od zmieniającego się zasobu wiedzy lekarskiej. Zmiana ta nie była identyfikowana $\mathrm{z}$ bezwzględnym przyrostem wiedzy, ale $\mathrm{z}$ istotną modyfikacją jej treści i struktury, powstającą w wyniku eliminacji ze standardu medycyny akademickiej elementów teoretycznych i praktycznych, które nie przeszły weryfikacji empirycznej. Europejski standard kliniczny, akceptowany też przez wielu lekarzy niemieckich, opierał się na podstawach filozofii sceptycznej i indywidualnych zdolnościach poznawczych osobowego podmiotu poznającego. Ponieważ kształtowana $\mathrm{w}$ ten sposób wiedza była obarczona ryzykiem błędu, zmierzano do stworzenia i stałego doskonalenia metodologii badań klinicznych, w wyniku której stosowania w praktyce weryfikowano kolejno tworzone przez lekarzy teorie i doktryny, a te spośród nich, które nie przeszły weryfikacji, eliminowano z programów nauczania.

18 Por. Ph.F. von Walther, Physiologie des Menschen, Landshut 1807; tenże, Abhandlungen aus dem Gebiete der practischen Medicin, Landshut 1810; tenże, Ueber den Geist des Universitätsstudium, Landshut 1811.

19 Por. M.A. Weikard, Der philosophische Arzt, Frankfurt am Main 1790; tenże, Medizinischpraktisches Handbuch auf Brownische Grundsätze und Erfahrung gegründet, t. 1-2, Heilbronn am Neckar 1796-1797; tenże, Sammlung medizinisch-praktischer Beobachtungen, Ulm 1798; tenże, Practische Anweisung zur Heilung örtlichen Krankheiten, Heilbronn am Neckar 1799.

${ }^{20}$ Por. L. Formey, Versuch einer medizinischen Topographie von Berlin, Berlin 1796.

${ }^{21}$ Por. A.F. Marcus, Kurze Beschreibung des allgemeinen Krankenhaus zu Bamberg, Weimar 1797; tenże, Ueber die Natur und Behandlungsart, Bamberg-Würzburg 1810.

22 Por. J.A. Schultes, Versuch eines Handbuches der Naturgeschichte des Menschen, Regensburg 1799; tenże, Ratio medendi, Solibacci 1826.

${ }^{23}$ Por. Ch.F. Nasse, De neuritide, Halae 1800.

${ }^{24}$ Por. A. Röschlaub, Ueber den Nutzen einer wohleingerichtetet medizinisch-klinischen Schule, Landshut 1803.

${ }^{25}$ Por. E. Horn, Versuch über die Natur und Heilung der Ruhr, Erfurt 1806.

26 Por. J.I. Stieglitz, Versuch einer Prüfung und Verbesserung der jetzt gewönlichen Behandlung des Scharlachtfiebers, Hannover 1807; tenże, Ueber den thierischen Magnetismus, Hannover 1814; tenże, Pathologische Untersuchungen, Hannover 1832.

27 Por. J.Ch. Hoffbauer, Physiologische Untersuchungen, Halle 1807.

28 Por. C.A.F. Kluge, Versuch einer Darstellung des animalischen Magnetismus als Heilmittel, Berlin 1811.

${ }^{29}$ Por. J.N. von Ringseis, De doctrina Hippocratica et Browniana, Norimbergae 1813.

${ }^{30}$ Por. Ch.H. Pfaff, Ueber Newton's Farbetheorie, Leipzig 1813; tenże, Ueber und gegen den thierischen Magnetismus, Hamburg 1817.

${ }^{31}$ Por. K.A. Rudolphi, Grundriss der Physiologie, Berlin 1821. 
Pod koniec XVIII w. nie doszło jednak do ukształtowania się wspólnego ogólnoeuropejskiego standardu medycyny, czemu stanęły na przeszkodzie czynniki światopoglądowe ${ }^{32}$, polityczne ${ }^{33}$ i wewnątrznaukowe ${ }^{34}$. Po wybuchu Wielkiej Rewolucji Francuskiej (1789), a szczególnie po nasileniu rewolucyjnego terroru (1792) przedstawiciele władz państwowych niemieckich krajów protestanckich zdecydowali się na stworzenie własnego modelu nauki akademickiej, odrzucającego filozofię oświecenia jako jego podstawę. Uznali bowiem, że jej szeroka aplikacja $\mathrm{w}$ szkolnictwie wszystkich szczebli prowadzi do rewolucji społecznej. Stworzony w Prusach w 1797 r. model medycyny akademickiej oparto w związku z tym na podstawach sprzecznych z filozofią oświecenia: religii protestanckiej, rodzimej filozofii idealistycznej i własnej tradycji medycznej o szesnasto- i siedemnastowiecznym rodowodzie, poprzedzającej sformułowanie postulatów programowych tzw. medycznego oświecenia ${ }^{35}$. Do reprezentatywnych przedstawicieli niematerialistycznego standardu niemieckiej medycyny klinicznej, wprowadzanego na uniwersytetach od 1797 r. drogą administracyjną przez władze kolejnych państw Rzeszy Niemieckiej, należeli Karl Friedrich Burdach ${ }^{36}$,

32 Por.: Medicine and the Reformation, red. O.P. Grell, London 1993; N. Tsouyopoulos, Der Einfluss des Neoplatonismus auf die Wissenschaft der Renaissance, „Sudhoff's Archiv für Geschichte der Medizin und der Naturwissenschaften" 60, 1976, z. 1, s. 33-44; D. Golz, Naturmystik und Naturwissenschaft in der Medizin um 1600, „Sudhoff's Archiv für Geschichte der Medizin und der Naturwissenschaften" 60, 1976, z. 1, s. 54-65; por. też: B. Płonka-Syroka, Imputacje kulturowe w standardzie niemieckiej medycyny romantycznej, w: Antropologia medycyny i farmacji w kontekście kulturowym, społecznym i historycznym, red. B. Płonka-Syroka, Wrocław 2008 (Studia Humanistyczne Wydziału Farmaceutycznego Akademii Medycznej we Wrocławiu, 1), s. 313-331; taż, Niemiecka medycyna romantyczna (1797-1848) w opiniach przedstawicieli polskiego środowiska naukowego do 1863 r., „Wiek XIX. Rocznik Towarzystwa Literackiego im. Adama Mickiewicza” 8(50), 2015, s. 101-119.

${ }^{33}$ Niemiecki standard romantyczny w medycynie został stworzony w opozycji wobec oświeceniowej nauki francuskiej. Szerzej na ten temat por. Revolution und Gegenrevolution 1798-1830: zur geistigen Auseinandersetzung in Frankreich und Deutschland, red. R. Dufraisse, München 1991; F.C. Breiser, Enlightenment, Revolution und Romanticism. The Genesis of Modern German Political Thought 1790-1800, Cambridge (Mass.) 1992; E. Weiss, Deutschland und Frankreich um 1800. Aufklärung - Gegenrevolution - Reform, München 1990; por. też B. Płonka-Syroka, Medycyna czasów Restauracji (1815-1848) na przykładzie medycyny akademickiej we Francji i Prusach, w: Medycyna i religia, t. 2, red. B. Płonka-Syroka, M. Dąsal (w przyg. do druku).

34 Szerzej na ten temat zob.: Z. Kuderowicz, Filozofia nowożytnej Europy, Warszawa 1980, s. 99-126; Paracelsus. Mikrokosmos und Makrokosmos: okkulte Schriften, red. H. Werner, München 1989; por. też: B. Płonka-Syroka, Niemiecka medycyna romantyczna... (2007), s. 94-102 i in; taż, Spór o model medycyny klinicznej w Europie (1750-1850): Francja, Austria i Prusy - odmienne warianty modernizacji, w: Zatargi, waśnie, konflikty. W perspektywie historycznej i kulturowej, red. K. Łeńska-Bąk, Opole 2015 (Stromata Anthropologica, 10), s. 163-176.

35 Por. B. Płonka-Syroka, Program romantyczny, w: taż, Niemiecka medycyna romantyczna... (2007), s. 241-244; taż, Podsumowanie, w: tamże, s. 244-246; taż, Wybrane problemy medyczne..., s. 299-353.

${ }^{36}$ Por. K.F. Burdach, Handbuch der Pathologie, Leipzig 1808; tenże, Der organismus menschlicher, Leipzig 1809; tenże, Die Physiologie, Leipzig 1810; tenże, Neues Rezepttaschenbuch, Leipzig 1811; tenże, Der Mensch nach verschieden Seiten sejner Natur, Stuttgart 1836. 
Carl Gustav Carus ${ }^{37}$, Lorenz Oken ${ }^{38}$, Johann Christian Reil ${ }^{39}$, Ignaz Paul Vital Troxler $^{40}$, Johann Christian August Heinroth ${ }^{41}$, Justinus Kerner ${ }^{42}$, Dietrich Georg Kieser ${ }^{43}$ i Johann Bernard Wilbrand ${ }^{44}$. W romantycznym standardzie klinicznym opublikowano w latach 1797-1848 tysiące prac, w tym podręczników i monografii klinicznych z zakresu różnych specjalności, artykułów teoretycznych i kazuistycznych, a także pisanych przez lekarzy dla szerszej publiczności opracowań popularnych. Metafizyczne podstawy romantycznego standardu interpretacyjnego, występujące we wszystkich pracach tego nurtu, dają się zebrać w następujący zestaw twierdzeń. 1) Świat jest stwarzany przez Boga w nieustającym akcie kreacji. Bóg kontroluje stale przebiegający proces stwarzania i panuje nad jego przebiegiem.

37 Por. C.G. Carus, Von dem Anforderungen an eine künftige Bearbeitung der Naturwissenschaften, Leipzig 1822; tenże, Erinnerung an die Vorlesung über Physiologie, Dresden 1829; tenże, Analecten zur Naturwissenschaft und Heilkunde, Dresden 1829; tenże, Vorlesungen über Physiologie, Leipzig 1831; tenże, System der Physiologie, Leipzig 1838; tenże, Zwölf Briefe über das Erdleben, Stuttgart 1841; tenże, Psyche, zur Entwicklungsgeschichte der Seele, Stuttgart 1851; tenże, Organon der Erkenntnis der Natur und des Geistes, Leipzig 1856; tenże, Über Lebensmagnetismus und über die magischen Wirkung überhaupt, Dresden 1857; tenże, Natur und Idee oder das Werdende und sein Gesetz. Eine philosophische Grundlage für specielle Naturwissenschaft, Wien 1861.

38 Por. L. Oken, Uebersicht des Grundriss des Sistems der Naturfilosofie, Frankfurt am Main 1802; tenże, Über das Universum als Fortsetzung des Sinnensystems, Jena 1808; tenże, Erste Ideen zur Theorie des Lichts, der Finsterniss, der Farben und der Wärme, Jena 1808; tenże, Okens Naturgeschichte für Schulen, Leipzig 1821; tenże, Lehrbuch der Naturphilosophie, Jena 1831.

39 Por. J.Ch. Reil, Rhapsodien über die Anwendung der psychischen Curmethoden, Halle 1803; tenże, Rhapsodien über die Anwendung der psychischen Kurmethoden, Halle 1818; tenże, Gedächtnisrede, Halle [1813].

${ }^{40}$ Por. I.P.V. Troxler, Versuche in der organische Physik, Jena 1804; tenże, Grundriss der Theorie der Medicin, Wien 1805; tenże, Ueber das Leben und sein Problem, Göttingen 1807; tenże, Blicke in das Wesen des Menschen, Aarau 1828; tenże, Vorlesungen über Philosophie, Bern 1835.

${ }^{41}$ Por. J.Ch.A. Heinroth, Grundzüge der Naturlehre des menschlichen Organismus, Leipzig 1807; tenże, Beiträge zur Krankheitslehre, Gotha 1810; tenże, De voluntate medici medicamento insaniae hypothesis, Lipsia 1818; tenże, Lehrbuch der Anthropologie, Leipzig 1811; tenże, Ueber die Wahrheit, Leipzig 1824; tenże, System der psychisch-gerichtlichen Medizin, Leipzig 1825; tenże, Anweisung für angehende Irrenärzte, Leipzig 1825; tenże, Antiorganon oder das Irrige des Hahnemannischen Lehre im Organon der Heilkunde dargestellt, Leipzig 1825; tenże, De materiae hypotesi quantun ad naturae scrutatores et medicos, Lipsiae 1827; tenże, Die Psychologie als Selbsterkenntnislehre, Lepizig 1827; tenże, Ueber die Hypothese der Materie und ihren Einfluss auf Wissenschaft und Leben, Leipzig 1828; tenże, Der Schlüssel zu Himmel und Hölle im Menschen, Leipzig 1829; tenże, Lehrbuch der Anthropologie, Leipzig 1831; tenże, Unterricht in zweckmässiger Selbstbehandlung bei beginenden Seelenkrankheiten, Leipzig 1834; tenże, Orthobiotik oder die Lehre vom richtigen Leben, Leipzig 1839; tenże, Gerichtliche und Privat-Gutachten hauptsächlich in Betreff zweifelhaften Seelenzustände, Leipzig 1847.

${ }^{42}$ Por. J. Kerner, Die Seherin von Prevorst, Stuttgart-Tübingen 1838; tenże, Blätter aus Prevorst, Karlsruhe 1831.

${ }^{43}$ Por. D.G. Kieser, System des Tellurismus oder thierischen Magnetismus, Jena 1822; tenże, Ueber die eigenthümliche Seelenstörung der sogenanten „Seherin von Prevorst”, Berlin 1831; tenże, Der Magnetismus im Verhältnisse zur Natur und Religion, Stuttgart-Tübingen 1853.

${ }^{44}$ Por. J.B. Wilbrand, Allgemeine Physiologie, Heidelberg-Leipzig 1833. 
Dzieje świata mogą być w związku z tym pojmowane jako obiektywizacja woli Bożej. 2) Idee powstałe $w$ umyśle Bożym znajdują $\mathrm{w}$ świecie swe odbicie. Są prawzorcem, z którego obiektywnego istnienia czerpią swe istnienie dostępne zmysłom byty. Są one jedynie przejawami obiektywnych idei, a nie obiektami materialnymi, którym przysługuje właściwość samodzielnego istnienia. 3) Wszelkie obserwowane w świecie zależności i związki wynikają z relacji pomiędzy ideami, a nie między jednostkowymi przejawami ich istnienia. $Z$ powyższych założeń wyprowadzano koncepcję uniwersum, w którym jest zanurzony człowiek i jego jednostkowa egzystencja. Świat ten pojmowano jako ożywioną Całość (Lebendige Ganze), w której istnieją obiektywne idee Życia, Gatunku i Ludzkości. Jednostka ludzka jest jedynie przejawem tych idei. Ludzki organizm powinien być w związku z tym pojmowany jako dusza obleczona w ciało, które podlega chorobom i śmierci. Są to procesy nieuchronne, których nie można powstrzymać ani zahamować. Choroby powstają przez oddziaływanie na duchową stronę ludzkiej egzystencji, gdyż dusza sprawuje bezpośrednią kontrolę nad przebiegiem wszystkich procesów fizjologicznych. Ich interpretowanie wyłącznie w kategoriach somatycznych romantycy uznawali za ograniczające zakres poznania naukowego i nieprowadzące do realistycznych rezultatów. Oddziaływanie na duszę wywołujące choroby może odbywać się w drodze bezpośrednich oddziaływań na nią samą (np. przez siły demoniczne) lub na ludzką wolę, skłaniającą człowieka do zachowań niemoralnych, wiodących nie tylko do grzechu, lecz także choroby. Patologiczne oddziaływania na duszę kontrolującą ludzką fizjologię mogą mieć także charakter pośredni, kiedy szkodliwe wpływy środowiska naturalnego oddziałują na ludzkie ciało, które traci zdolność odbierania sygnałów duszy. Choroby mogły powstawać także wówczas, gdy w ludzkim organizmie następowało niedokładne, nieprawidłowe odzwierciedlenie idei konstytuujących ludzkie ciało. Szczegółowe omówienie romantycznego standardu medycyny nie jest możliwe do przedstawienia w ramach jednego artykułu, czytelników zainteresowanych głębszą analizą jego treści odsyłam więc do piśmiennictwa zebranego w przedstawionych w przypisie pierwszym monografiach. By jednak wskazać podstawę oceny tego standardu wyrażanej w XIX i XX stuleciu w historiografii, trzeba podkreślić te jego cechy, które najbardziej dobitnie różniły ów standard od głównego nurtu modernizacyjnego europejskiej medycyny klinicznej, tworząc kontekst uzasadnień ocen o charakterze krytycznym. Po pierwsze, w romantyczny standard interpretacyjny zostały wbudowane byty niepoddające się poznaniu empirycznemu, które zostało uznane za podstawę medycyny klinicznej inspirowanej filozofią oświecenia. Wpisanie ludzkiego organizmu z strukturę złożoną z obiektywnych idei Całości, Życia, Gatunku i Ludzkości implikowało specyficzny rodzaj antropologii, która z punktu widzenia lekarzy europejskich wydawała się oparta na spekulacjach i irracjonalna. Drugim ważnym przedmiotem różnic były epistemologiczne postawy medycyny w obu standardach klinicznych. W standardzie somatycznym źródłem wiedzy naukowej jest osobowy 
podmiot, jednostka obdarzona pełnią władz poznawczych, samodzielnie stawiająca hipotezy i zmierzająca do ich empirycznej weryfikacji. Przedmiotem poznania jest natomiast obiektywnie istniejąca rzeczywistość o trwałych cechach, której istnienie podlega prawom przyrody. Bytem materialnym będącym przedmiotem szczególnej uwagi medycyny klinicznej jest ludzkie ciało, zdolny do samodzielnego życia organizm, zakorzeniony w otaczającym środowisku przyrodniczym, które wywiera nań różnego rodzaju wpływy. Środowisko zarówno podtrzymuje organizm przy życiu (przez funkcje oddychania czy odżywiania), jak i może być dla niego szkodliwe (przegrzanie, wyziębienie, zatrucie itp.). W głównym nurcie medycyny klinicznej uznano, że tworzone przez lekarzy teorie i doktryny mają z natury rzeczy charakter obarczony błędem, wymagają więc weryfikacji za pomocą specjalnie stworzonych procedur. Nie uzyskują statusu wiedzy obiektywnej i prawdziwej raz na zawsze, ponieważ wraz ze wzrostem kompetencji poznawczych społeczności akademickiej, udoskonaleniami sprzętu, nowymi obserwacjami mogą być zastąpione przez inne, bardziej płodne, umożliwiające realny wzrost efektywności leczenia. W standardzie romantycznym natomiast wiedza medyczna ma charakter tzw. wiedzy bezpośredniej, uzyskiwanej przez jednostki w specjalnym stanie świadomości. Rzetelna wiedza opiera się na prawdzie, jest stała i niezmienna, ponieważ opiera się na dedukcji z prawd podstawowych, a nie na wnioskowaniu z relacji między przejawami idei obiektywnych. Przedmiotem poznania jest obiektywny świat idei, do którego dostęp jest możliwy jedynie w drodze racjonalnej dedukcji albo $\mathrm{w}$ jednorazowym, bezpośrednim akcie poznania przypominającym wgląd $\mathrm{w}$ istotę rzeczy. Fizjologia i patologia romantyczna opierały się w związku z tym na dedukcji, wyprowadzanej z kilku prostych twierdzeń przyjmowanych za pewne. Nie udało się jednak stworzyć spójnego systemu fizjologii i patologii akceptowanego na wszystkich uniwersytetach uznających standard romantyczny. Stało się tak dlatego, że rywalizujące ze sobą koncepcje tworzone przez konkurujących ze sobą uczonych nie miały wbudowanych w swą strukturę kryteriów ich weryfikacji. Ich weryfikacja empiryczna nie była uznawana za naukową, a - jak wiadomo - spójnych wewnętrznie hipotez opartych na dedukcji może być nieskończenie wiele, a każdy z twórców takiej hipotezy swoją własną przedstawiał jako opartą na prawdzie, realistyczną i obiektywną, odmawiając tych dystynkcji innym.

W pierwszej połowie XIX stulecia funkcjonowały w europejskiej medycynie klinicznej dwa rywalizujące ze sobą standardy medycyny akademickiej w Europie, których podstaw teoretycznych oraz treści nie dało się uzgodnić. Zwolennicy każdego z nich pisali historię medycyny klinicznej z własnego punktu widzenia, kreując $w$ swoich pracach odmienny obraz tej epoki, podkreślając zasługi i wypominając błędy różnych działających w nich bohaterów. W drugiej połowie XIX w. europejski standard medycyny klinicznej uległ jednak scaleniu w nawiązaniu do oświeceniowych podstaw reformy klinicznej z lat 50. XVIII w., co spowodowało, że w europejskiej historiografii medycyny ogólna ocena standardu niemieckiej 
medycyny romantycznej była już we wszystkich krajach taka sama - negatywna co do zasady, różniąca się jednak co do szczegółów. Możemy wyróżnić zasadnicze etapy procesu ujednolicania standardu medycyny klinicznej w Europie, które wywarły późniejszy wpływ na jej historiografię. 1) Lata 50. XVIII w.: cesarzowa Maria Teresa usunęła arystotelizm z uniwersytetów w Austrii i wydała zgodę na jego zastąpienie przez newtonizm. Zgodę papieża na wprowadzenie fizyki Newtona na uniwersytety w krajach katolickich uzyskał jezuicki fizyk i astronom Rudjer Josip Boškovič. W 1760 r. zostało wydane w Tyrawie Breviarium, zawierające skrótowe omówienie tej fizyki, która została także oficjalnie wprowadzona w szkołach średnich. W ten sposób stworzone zostały nowe podstawy fizyczne dla ustanowienia na uniwersytetach krajów katolickich nowego standardu medycyny akademickiej, uwzględniającego nowy sposób fizycznego opisywania świata ${ }^{45}$. Pierwszą i najbardziej wpływową szkołą naukową opartą na nowym standardzie interpretacyjnym była Starsza Szkoła Wiedeńska związana z Uniwersytetem Wiedeńskim. Szkoły medyczne oparte na nowym standardzie klinicznym powstały także w innych krajach katolickich - we Francji, krajach włoskich i z pewnym opóźnieniem także w Polsce. 2) Lata 80. XVIII w.: w 1784 r. we Francji zostają wydane postanowienia trzech komisji naukowych, zawierające reguły weryfikacji teorii i doktryn medycznych jako naukowych. Na przykładzie doktryny medycznej Franza Antona Mesmera, który zabiegał o uznanie przez środowisko naukowe Francji jej wartości naukowej, Komisja Francuskiej Akademii Nauk, Komisja Paryskiego Fakultetu Medycznego i Komisja Królewska wydały postanowienie, zgodnie z którym każda koncepcja naukowa wykładana na uniwersytetach musi być zgodna $\mathrm{z}$ aktualnym stanem przyrodoznawstwa ${ }^{46}$. Postanowienia z $1784 \mathrm{r}$. umożliwiały eliminację z medycyny akademickiej koncepcji stworzonych wcześniej, czasem jeszcze o starożytnym rodowodzie, które nie przeszły weryfikacji empirycznej. Stanowiły także barierę uniemożliwiającą wprowadzenie do nauki i dydaktyki uniwersyteckiej koncepcji nowych, których podstawy teoretyczne uznano za irracjonalne, albo też fakty, których podstawą była oceniana teoria, nie uzyskały potwierdzenia w badaniach niezależnych badaczy. Przyjęte wówczas procedury miały jednak istotną wadę, nie określały bowiem w sposób jednoznaczny kolejnych kroków postępowania w procesie weryfikacyjnym. Umożliwiało to wywodzenie sprzecznych ze sobą hipotez z tych samych faktów, dobrze potwierdzonych empirycznie. 3) Lata 50. XIX w.: opracowanie przez Claude’a Bernarda

${ }^{45}$ Por. B. Płonka-Syroka, Medycyna niemiecka nurtu niematerialistycznego..., s. 67, 177.

46 Por. taż, Mesmeryzm. Od astrologii do bioenergoterapii, wyd. 3 rozsz., Wrocław 2007. Przedstawiam tu starania uczonych prowadzących badania nad zjawiskiem hipnozy począwszy od lat 60. XVIII do lat 60. XIX w. Dopiero po stu latach od rozpoczęcia przez F.A. Mesmera tych starań okazało się możliwe uznanie naukowego charakteru koncepcji medycznych dotyczących zjawiska hipnozy. James Braid potrafił bowiem spełnić wymagania postawione w $1784 \mathrm{r}$. przez komisje paryskie. 
ścisłych zasad metodologii medycyny eksperymentalnej doprowadziło do ujednolicenia reguł prowadzenia doświadczeń klinicznych ${ }^{47}$. Stosując $\mathrm{w}$ praktyce opisane przez francuskiego uczonego procedury, nie można było obalić wyników eksperymentów medycznych, jeżeli zostały prawidłowo przeprowadzone. W ciągu dziesięciu lat doprowadziło to do ukształtowania się w medycynie europejskiej standardu bakteriologii, która określiła podstawy rozwoju medycyny na następnych sto lat. Ponieważ bakteriologia została wyprowadzona z założeń głównego nurtu klinicznego w Europie, a nie z niemieckiego standardu romantycznego, standard ten został powszechnie odrzucony jako irracjonalny. Znalazło to odbicie zarówno w medycynie klinicznej drugiej połowy XIX w., jak i w powstającej $\mathrm{w}$ tym okresie historiografii.

Przystępując do omówienia kolejnych etapów kształtowania się obrazu niemieckiej medycyny romantycznej w historiografii, wyjaśnić trzeba cezurę początkową występującą w niniejszym artykule (1811), różniącą się od daty inicjującej początek omawianej epoki (1797). Wcześniejsza z tych dat stanowi cezurę w historii medycyny niemieckiej wyznaczoną przez konkretne działania pruskiego ośrodka władzy zmierzającego do stworzenia standardu medycyny akademickiej alternatywnego wobec standardu medycyny francuskiej i (częściowo) austriackiej. Silne szkoły medyczne działające w obu tych krajach odwoływały się w swych podstawach do założeń metafizycznych i filozoficznych, które dla pruskich władz państwowych były trudne do przyjęcia. Ze względu na znaczne sukcesy poznawcze i praktyczne osiągane w drugiej połowie XVIII w. przez medycynę austriacką i francuską nie można było przejść nad nimi do porządku dziennego, lecz należało tamtejszym szkołom naukowym przeciwstawić równie złożony w teorii i praktyce system, którego podstawy byłyby akceptowane przez pruskie władze. Do 1848 r. stworzony w 1797 r. system był podtrzymywany w pruskiej medycynie uniwersyteckiej drogą nakazowo-administracyjną. Do jego obalenia przyczyniła się głównie jego nieefektywność i niezdolność sprostania przez niemiecką medycynę akademicką istotnym wyzwaniom społecznym ${ }^{48}$ i naukowym ${ }^{49}$. Data $1811 \mathrm{r}$. wiąże się natomiast

${ }^{47}$ Por. G. Buchholz, Die Medizintheorie Claude Bernard's: ihr philosophischer und wissenschaftlicher Hintergrund, Murken 1985.

${ }^{48}$ Por. B. Płonka-Syroka, Wpływ czynników społeczno-politycznych na kształtowanie się systemu medycyny publicznej w Prusach i zjednoczonych Niemczech do 1914 r., w: Czystość i brud. Higiena w XIX wieku. Wokół przełomu bakteriologicznego, red. W. Korpalska, W. Ślusarczyk, Bydgoszcz 2016 (w druku).

${ }^{49}$ Por. taż, Wplyw czynników wewnątrznaukowych i zewnatrznaukowych na ukształtowanie się systemu zabezpieczeń przeciwepidemicznych $w$ Europie Zachodniej (na przykładzie wybranych państw), w: taż, Medycyna w historii i kulturze... (2016), s. 316-326; por. też taż, Koncepcja profilaktyki medycznej Christopha Wilhelma Hufelanda w kontekście historyczno-porównawczym, w: tamże, s. 348-355, 387-390, 408-417. 
z wprowadzeniem w Prusach historii medycyny jako obowiązkowego przedmiotu nauczania $\mathrm{w}$ programie studiów medycznych, $\mathrm{w}$ tym $\mathrm{w}$ na nowo założonych uniwersytetach w Berlinie i we Wrocławiu, które miały czynnie uczestniczyć we wdrażaniu zaprojektowanej wcześniej reformy programowej.

W latach 1811-1848 możemy wyróżnić w niemieckojęzycznej historiografii medycyny dwa nurty teoretyczne, poddające ocenie współczesny sobie standard rodzimej medycyny akademickiej. W tym okresie prace poświęcone tej tematyce powstawały wyłącznie w nauce niemieckiej, gdyż europejskie środowisko lekarskie nie uznawało za stosowne poddawać analizom niemieckiego standardu romantycznego, który oceniany był jako anachroniczny ${ }^{50}$. Historia medycyny była ówcześnie na europejskich uniwersytetach ważnym przedmiotem praktycznym, dostarczającym studentom niezbędnej erudycji w zakresie faktów klinicznych i ich możliwych interpretacji, stanowiąc punkt odniesienia dla interpretacji współczesnych. W niemieckojęzycznej historiografii medycyny z pierwszej połowy XIX w., austriackiej i inspirowanej przez Uniwersytet Wiedeński dominował punkt widzenia na kwestie kliniczne wypracowany w Starszej Szkole Wiedeńskiej i lokalnych szkołach klinicznych powstających w innych państwach Rzeszy Niemieckiej, będących jej kontynuacją. Ten sam punkt widzenia występował także $w$ opisach zmian standardu medycyny z ostatnich trzech stuleci. Pozytywną waluację znajdował $\mathrm{w}$ nich proces somatyzacji medycyny i jej zakorzenienia w naukach o przyrodzie, dążenie do oparcia fizjologii na podstawach anatomicznych, poszukiwanie przyczyn chorób w materialnych wpływach środowiska naturalnego na organizm ludzki. Przedstawicielami takiego ujęcia teoretycznego w niemieckojęzycznej historiografii medycyny byli m.in. August Friedrich Hecker ${ }^{51}$, Friedrich Ludwig Augustin ${ }^{52}$,

${ }^{50}$ Uczeni europejscy z przełomu XVIII i XIX w., w tym także polscy - np. Jędrzej Śniadecki zauważali, że standard niemieckiej medycyny romantycznej powstaje w bezpośrednim nawiązaniu do nauki niemieckiej z XVII w., usiłując usunąć z obowiązującego w szkolnictwie standardu cały dorobek związany z myślą naukową i filozoficzną oświecenia. Uznawali ten zabieg za niemożliwy do przeprowadzenia bez uszczerbku dla efektywności medycyny jako nauki praktycznej. Teoretyczną stronę niemieckiego standardu romantycznego uważali za irracjonalną; por. taż, Jędrzej Śniadecki wobec brownizmu - kontekst kulturowy i podstawy teoretyczne jego praktyki interpretacyjnej, w: taż, Niemiecka medycyna romantyczna... (2007), s. 445-459.

${ }^{51}$ Por. A.F. Hecker, Die Heilkunst auf ihren Wegen zur Gewissheit oder die Theorien, Systeme und Heilmethoden der Aerzte seit Hippokrates bis auf unsere Zeiten, Wien 1802. Praca ta była wznawiana w latach 1803, 1805, 1808, 1813 i 1820. Podręcznik Heckera, stale doskonalony i poszerzany, był wykorzystywany na uniwersytetach $\mathrm{w}$ wielu krajach Rzeszy Niemieckiej, przede wszystkim w Austrii i krajach katolickich, aż do lat 40. XIX w., kiedy został zastąpiony przez nowe opracowania, dostosowane do zmian w standardzie medycyny klinicznej. Nie wszystkie bowiem koncepcje opisywane na przełomie XVIII i XIX w. przez Heckera jako „obiecujące” przetrwały próbę czasu. Nie zmieniło się jednak w nowych podręcznikach historii medycyny zasadnicze ujęcie teoretyczne występujące u tego autora - pozytywna ocena procesu modernizacji medycyny zgodnego z głównym nurtem klinicznym.

52 Por. F.L. Augustin, Handbuch der allgemeinen medicinischen Therapie, Berlin 1806 (reprint: $1825)$. 
R.H. Rohatzsch ${ }^{53}$, Burkhard Eble ${ }^{54}$, Georg Friedrich Most $^{55}$ i Bernhard Hirschel ${ }^{56}$. Wspomniany nurt $\mathrm{w}$ niemieckiej historiografii medycyny jest nazywany nurtem eklektycznym, gdyż jego podstawowym założeniem było dostarczenie studentom medycyny jak największej liczby faktów klinicznych umożliwiających im samodzielną interpretację obserwacji. Autorzy omawianych tu prac nie podejmowali polemiki ze standardem niemieckiej medycyny romantycznej traktowanym jako całość, ale analizowali występujące w niej pojedyncze koncepcje, oceniając sposób interpretacji faktów klinicznych, który był charakterystyczny dla każdej z nich. Ocena ta była uzależniona od tego, czy omawiana koncepcja wyprowadzała swą teorię z doświadczenia, czy też była formułowana w sposób aprioryczny, tj. przed doświadczeniem, dostosowując wyniki badań klinicznych do pierwotnych założeń. Ponieważ doktryny niemieckiej medycyny romantycznej należały do tej drugiej kategorii, były bądź to w ogóle pomijane w podręcznikach historii medycyny pisanych z perspektywy głównego nurtu klinicznego medycyny europejskiej, bądź też wspominano o nich niewiele i krytycznie.

Już po usunięciu standardu romantycznego $\mathrm{z}$ niemieckiej medycyny akademickiej, tj. po 1849 r., w tym samym ujęciu metodologicznym powstawały kolejne prace historyczne, z których największy wpływ na niemiecki (i środkowoeuropejski, w tym polski) sposób interpretacji w historiografii medycyny epoki niemieckiego romantyzmu medycznego miał podręcznik Heinricha Haesera ${ }^{57}$. Interpretacja ta uwypuklała $\mathrm{w}$ dziejach medycyny niemieckiej z pierwszej połowy XIX w. postacie tych lekarzy, których poglądy naukowe pozostawały w jakimś związku z głównym nurtem europejskiej medycyny klinicznej, działalność i poglądy pozostałych pomijając milczeniem albo poddając je krytyce. Najczęściej stawianym im zarzutem była wtórność względem koncepcji medycznych stworzonych wcześniej przez lekarzy europejskich ${ }^{58}$, przyjmowanych przez lekarzy niemieckich bezkrytycznie i kontynuowanych z pozycji epigonalnych, pomimo krytyki, $\mathrm{z}$ jaką już się spotkały w głównym nurcie klinicznym medycyny europejskiej.

${ }^{53}$ Por. R.H. Rohatzsch, Compendiose Geschichte der Medizin, Stuttgart 1839.

54 Por. B. Eble, Die Geschichte der Praktischen Arzneikunde (Systeme, Epidemien, Heilmittel, Bäder) vom Jahre 1800-1825, Wien 1840.

55 Por. G.F. Most, Ueber alte und neue medicinische Lehrsysteme im Allgemeinen und über Dr. J.L. Schönlein's neuestes natürliches System der Medicin insbesondere. Ein historisch-kritischer Versuch, Leipzig 1841.

${ }^{56}$ Por. B. Hirschel, Geschichte des Brownschen Systems und der Erregungstheorie, Dresden-Leipzig 1846.

57 Por. H. Haeser, Lehrbuch der Geschichte der Medizin, Jena 1853. Podręcznik ten miał w języku niemieckim wiele wydań. Wydanie trzecie, z lat 1876-1881, zostało przetłumaczone przez Henryka Łuczkiewicza na język polski (H. Haeser, Dzieje medycyny nowożytnej, t. 2, tłum. H. Łuczkiewicz, Warszawa 1886), kształtując aż do lat 30. XX w. wśród polskich czytelników obraz tej epoki. Było dostępne zarówno w wydaniu książkowym, jak i - drukowane we fragmentach - na łamach czasopism lekarskich.

${ }^{58} \mathrm{~Np}$. Röschlauba wobec szkockiego lekarza Johna Browna; tamże, s. 677-693. 
Wydając swoją syntezę historyczną zaledwie cztery lata po usunięciu standardu medycyny romantycznej z niemieckich uniwersytetów, Haeser dostrzegał złożoność teoretyczną eliminowanej struktury. Wykładane przed 1848 r. na tych uczelniach teorie i doktryny medyczne wpisał w różne tradycje interpretacyjne występujące wcześniej w medycynie europejskiej. Wyróżnił wśród nich nurt witalistyczny ${ }^{59}$, dynamiczny ${ }^{60}$ oraz nawiązujący w swych podstawach do neoplatonizmu ${ }^{61}$. Zwrócił także uwagę na ogromne znaczenie szkockiej doktryny Johna Browna dla kształtowania się niematerialistycznego standardu medycyny niemieckiej od przełomu XVIII i XIX w. aż po połowę tego stulecia. Uznał powszechną recepcję brownizmu w medycynie niemieckiej za jedną z przyczyn zahamowania jej rozwoju. Odniósł się także krytycznie do osiągnięć jednej z najbardziej wpływowych przed $1848 \mathrm{r}$. niemieckich szkół naukowych, związanej ze standardem romantycznym, tzw. szkoły naturalno-historycznej stworzonej przez Lucasa Schönleina ${ }^{62}$. Haeser traktował okres tzw. urzędowego obowiązywania na niemieckich uniwersytetach standardu medycyny romantycznej jako zamkniętą epokę, z której należy wyciągnąć wnioski na przyszłość. Zamknięcie się niemieckiej medycyny akademickiej na inspiracje czerpane z głównego nurtu klinicznego tworzonego w XVIII stuleciu i oparcie się na koncepcjach wobec niego wcześniejszych czyniło medycynę niemiecką wtórną wobec osiągnięć naukowych Europy i anachroniczną wobec europejskiego standardu klinicznego. Sposób kształtowania narracji w podręczniku historii medycyny tego autora cechuje staranność w doborze faktów i precyzyjny sposób ich interpretacji. Metoda Haesera polegała na dokładnym opisie analizowanych koncepcji medycznych, ukazaniu ich związków z wcześniejszymi teoriami i przedstawieniu najważniejszych kierunków ich recepcji. Haeser omawiał znaczenie tych koncepcji w epoce, w której powstały oraz oceniał je z punktu widzenia współczesnej mu wiedzy medycznej. Dzięki wyraźnemu oddzieleniu faktów od ocen praca Haesera miała duże znaczenie poznawcze i propedeutyczne. Umożliwiła bowiem wykładowcom historii medycyny w ciągu następnego półwiecza formułowanie nowych interpretacji, nawiązujących do zmieniającego się standardu wiedzy akademickiej.

Negatywna ocena wybranych dokonań niemieckiej medycyny romantycznej sformułowana przez historyków medycyny związanych z nurtem klinicznym, publikujących przed 1848 r. i krótko po usunięciu tego standardu z uniwersytetów (1849), została podtrzymana $\mathrm{w}$ wielu wydawanych do końca wieku podręcznikach historii medycyny oraz opracowaniach monograficznych opartych na tych samych teoretycznych założeniach. Przykładowe prace tego nurtu to opracowania Heinricha Rohlfsa ${ }^{63}$,

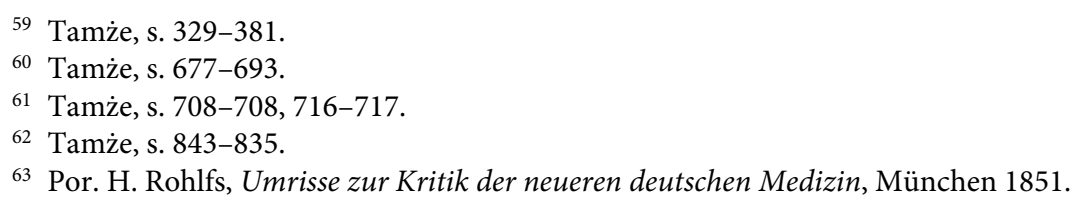


Carla Guttlera ${ }^{64}$, Karla Du Prella ${ }^{65}$ i Alfreda Hubera ${ }^{66}$. Po 1850 r. pojawiły się także w niemieckim piśmiennictwie historycznomedycznym określenia deprecjonujące oficjalny standard niemieckiej medycyny klinicznej niedawno minionej epoki, takie jak naturphilosophische Medizin oraz romantische Medizin. Określenia te miały wskazywać na zakorzenienie owego standardu w supranaturalistycznej filozofii przyrody lub poezji, nie w opartej na właściwych podstawach naukowych metodologii medycyny klinicznej. Omawiany tu standard historiografii medycyny określamy jako klasyfikację jednobiegunową, ponieważ niemiecki standard akademicki z lat 1797-1848 jest w niej traktowany jako pewna całościowa, choć wewnętrznie zróżnicowana struktura, która została usunięta $\mathrm{z}$ uniwersytetów jako błędna i nie znajdowała w nauce niemieckiej kontynuacji. W ramach tego nurtu pojawiały się również prace podkreślające dokonania naukowe wybranych lekarzy niemieckich, którzy w ogólnie negatywnie ocenianej epoce utrzymali związki z europejską medycyną naukową. Należeli do tego grona m.in. Christoph Wilhelm Hufeland ${ }^{67}$, Johannes Müller ${ }^{68}$ czy Johann Israel Stieglitz ${ }^{69}$. Za główną ich zasługę - niezależnie od konkretnych osiągnięć naukowych, które z perspektywy czasu miały już wyłącznie znaczenie historyczne - uznano korzystanie przez nich z metodologii badań klinicznych opartej na doświadczeniu i obserwacji (tj. takiej samej jak w głównym nurcie klinicznym), a nie na spekulacjach filozoficznych niemieckiej idealistycznej filozofii przyrody.

W niemieckim piśmiennictwie historycznomedycznym powstającym przed 1848 r., a więc w okresie dominacji na uczelniach standardu medycyny romantycznej, powstawały także prace odnoszące się do tego standardu w sposób afirmatywny. Celem ich autorów było napisanie syntez historii medycyny europejskiej, w których punktem odniesienia zawartych w nich ocen byłby współczesny niemiecki standard romantyczny. W niemieckiej historiografii medycyny nurt ten jest określany mianem nurtu filozoficznego, ze względu na to, że odnosił się z aprobatą zarówno do niemieckiej idealistycznej filozofii przyrody, stanowiącej podstawę niemieckiego romantycznego standardu klinicznego w latach 1797-1848, jak i do tych wcześniejszych kierunków w filozofii europejskiej, które były podstawą dla teorii i doktryn alternatywnych wobec głównego europejskiego nurtu modernizacyjnego w medycynie. Do publikacji reprezentatywnych

${ }^{64}$ Por. C. Guttler, Lorenz Oken und sein Verhältnis zur modernen Entwicklungstheorie, Leipzig 1884.

${ }^{65}$ Por. K. Du Prell, Justinus Kerner und się Seherin von Prevorst, Leipzig 1886.

${ }^{66}$ Por. A. Huber, Studien zu Novalis, mit besonderer Berücksichtigung der Naturphilosophie, „Euphorion” 4, 1899, z. 9.

${ }^{67}$ Por. F. Bachmann, Die drei Kardinalmittel der Heilkunst Hufelands, ein Beitrag zum Vergleiche ärztlicher Kunst einst und jetzt, München 1886.

${ }^{68}$ Por. Th.L.W. Bischof, Johannes Müller und sein Verhältnis zum jetzigen Standpunkt der Physiologie, München 1858.

${ }^{69}$ Por. H. Rohlfs, Die medizinischen Klassiker Deutschlands, t. 1, Stuttgart 1875, s. 248. 
dla omawianego tu nurtu należą podręczniki i monografie autorstwa Johanna Michaela Leupoldta ${ }^{70}$, Heinricha Damerowa ${ }^{71}$, Wilhelma Josepha Antona Webera ${ }^{72}$, Mathiasa Josefa Bluffa ${ }^{73}$, Ernsta Antona Quitzmanna ${ }^{74}$, Michaela Benedikta Lessinga $^{75}$, Ludwiga Hermanna Friedländera ${ }^{76}$ i Emila Isensee ${ }^{77}$. Po 1850 r. należące do omawianego nurtu prace zdezaktualizowały się i zostały zastąpione $\mathrm{w}$ niemieckim szkolnictwie uniwersyteckim przez inne, pisane z punktu widzenia europejskiego standardu klinicznego, w tym głównie przez podręcznik Heinricha Haesera, który uzyskał w drugiej połowie XIX w. status klasyka niemieckiej historiografii medycyny.

W latach 1850-1900 w niemieckim piśmiennictwie historycznomedycznym pojawiło się nowe ujęcie teoretyczne, tzw. ujęcie dwubiegunowe. Jego podstawą była próba klasyfikacji licznych szkół niemieckiej medycyny klinicznej o sprzecznych ze sobą standardach, funkcjonujących na niemieckich uniwersytetach w latach 1797-1848. Zwolennicy tego ujęcia zaproponowali wprowadzenie wśród nich podziału opartego na zasadniczej opozycji teoretycznej: jedne szkoły klasyfikowali jako zbliżone lub chociaż w pewnych punktach zbieżne z głównym europejskim standardem klinicznym, natomiast drugie jako mniej lub bardziej opozycyjne wobec tego standardu. Było to ujęcie sztuczne, związane $\mathrm{z}$ reinterpretacją treści źródeł i eliminowaniem $\mathrm{z}$ nich niezgodnych $\mathrm{z}$ założeniami tego nurtu elementów, ponieważ $\mathrm{w}$ pierwszej połowie XIX w. na żadnym z niemieckich uniwersytetów nie funkcjonowała szkoła naukowa $\mathrm{w}$ pełni zgodna $\mathrm{z}$ głównym europejskim standardem klinicznym, a w każdej z nich można było odnaleźć elementy opozycyjne wobec niego. Autorom tworzącym swoje prace zgodnie $\mathrm{z}$ ujęciem dwubiegunowym zależało jednakże na przezwyciężeniu dotychczasowego ujmowania epoki niemieckiej medycyny romantycznej jako swoistej „czarnej dziury”, w której cała niemiecka medycyna kliniczna funkcjonowała na obrzeżach nauki europejskiej, ustosunkowując się krytycznie do jej standardu i nie odnosząc żadnych poznawczych i praktycznych sukcesów, ze względów na swój epigonalny charakter wobec

70 Por. J.M. Leupoldt, Allgemeine Geschichte der Heilkunde, Erlangen 1825.

71 Por. H. Damerow, Die Elemente der nächsten Zukunft der Medicin entwickelt aus der Vergangenheit und Gegenwart, Berlin 1829.

72 W.J.A. Weber, Über Gegensatz, Wendepunkt und Ziel der heutigen Physiologie und Medizin zur Vermittlung der Extreme besonders der Allopatie und Homöopathie, cz. 1: Entwicklungsgeschichte der Physiologie und Medizin, Leipzig 1837.

73 Por. M.J. Bluff, Reform der Heilkunst, Leipzig 1837.

${ }^{74}$ Por. E.A. Quitzmann, Von den medizinischen Systeme und ihrer geschichtlichen Entwicklung, München 1837; tenże, Die Geschichte der Medizin in ihren gegenwärtigen Zustande, t. 1-2, Karlsruhe 1843.

75 Por. M.B. Lessing, Handbuch der Geschichte der Medizin, Berlin 1838.

${ }^{76}$ Por. L.H. Friedländer, Vorlesungen über die Geschichte der Heilkunde, Leipzig 1839.

77 Por. E. Isensee, Geschichte der Medizin, Chirurgie, Geburtshilfe, Staatsarzneikunde, Pharmazie und anderer Naturwissenschaften und ihrer Literatur, t. 1-6, Berlin 1840-1845. 
stanu badań współczesnej medycyny w innych krajach Europy, w tym przede wszystkim we Francji. Historycy medycyny piszący w omawianej tu konwencji stworzyli obraz epoki romantycznej w niemieckiej medycynie klinicznej jako okresu sporów toczonych w niemieckiej społeczności naukowej, w których na jednym biegunie plasowali się zwolennicy zachowania pewnych związków ze standardem medycyny głównego nurtu i kontynuacji standardu teoretycznego europejskiego oświecenia medycznego, natomiast na drugim zwolennicy stworzenia oryginalnego niemieckiego standardu klinicznego, całkowicie odrzucający możliwość zachowania w niemieckiej medycynie elementów zgodnych z osiemnastowiecznym standardem medycyny w Europie oraz teoriami i doktrynami opartymi na podstawach empirycznych i filozofii sceptycznej, będącymi jego kontynuacją w pierwszej połowie XIX w. Głównym bohaterem pozytywnym w dwubiegunowym modelu historiografii stał się znakomity berliński klinicysta Christoph Wilhelm Hufeland ${ }^{78}$, który od 1795 aż do 1838 r. dzięki swoim licznym publikacjom o standardzie zbliżonym do obowiązującego w Starszej Szkole Wiedeńskiej i długoletniej działalności nauczycielskiej na Uniwersytecie Berlińskim utrzymał związki niemieckiej medycyny klinicznej z medycyną europejską. Akceptując ten sposób interpretacji faktów historycznych z dziejów niemieckiej medycyny klinicznej, można było wykazać, że między śmiercią Hufelanda (1838) a wyparciem standardu romantycznego z niemieckich uniwersytetów (1849) upłynął tylko krótki okres, w którym na wydziałach lekarskich dominowały koncepcje skrajnie sprzeczne z nauką europejską. Nie była to przy tym dominacja całkowita, ponieważ $\mathrm{w}$ niemieckim środowisku lekarzy praktyków, zrzeszonych w różnych ogólnoniemieckich i lokalnych towarzystwach naukowych, romantyczny standard medycyny już od lat 30. XIX w. bywał otwarcie kontestowany.

W drugiej połowie XIX w. pojawiło się w niemieckiej historiografii medycyny tzw. ujęcie trójbiegunowe epoki niemieckiej medycyny romantycznej, związane $\mathrm{z}$ recepcją standardu pozytywistycznego wśród autorów niemieckich. Akceptowali oni występujący w metodologii pozytywistycznej podział na trzy epoki: nienaukową, przednaukową i naukową. Zakładali, że zasadniczo następują one kolejno po sobie, jednakże omawiając $w$ publikacjach okres niemieckiego romantyzmu medycznego, odnajdywali w nim ślady każdej z nich, współwystępujące ze sobą w tym samym czasie. Standard teoretyczny niemieckich szkół medycyny klinicznej $\mathrm{z}$ lat 1797-1848 był przedstawiany $\mathrm{w}$ pracach omawianego nurtu jako złożony z trzech rywalizujących ze sobą nurtów: zgodnego (w najbardziej ogólnym zarysie) z głównym standardem medycyny europejskiej, niezgodnego z tym standardem $\mathrm{w}$ wielu zasadniczych kwestiach oraz pozostającego zupełnie poza granicami

${ }^{78}$ Por. K. Pfeifer, Medizin der Goethezeit. Christoph Wilhelm Hufeland und die Heilkunst des 18. Jahrhunderts, Köln-Weimar-Wien 2000. Praca zawiera bibliografię prac poświęconych Hufelandowi i jego szkole naukowej, powstałych w drugiej połowie XIX i w XX w. 
poznania naukowego, ze względu na reguły akceptowanej metodologii i włączanie do obrazu świata (tj. do sfery faktów uznawanych za realne) bytów nieuznawanych za istniejące nie tylko w europejskim środowisku lekarzy klinicznych, lecz także $\mathrm{w}$ gronie niemieckich lekarzy uniwersyteckich akceptujących standard romantyczny. Celem tego rodzaju konceptualizacji było wyraźne oddzielenie w opisie standardu niemieckiej medycyny romantycznej koncepcji całkowicie irracjonalnych, traktowanych w ten sam krytyczny sposób zarówno przez lekarzy europejskich, jak i niemieckich (takich jak np. homeopatia S.F. Hahnemanna, odomagnetyzm K. Reichenbacha, spirytualizm J. Kernera), od tych, które spotykały się wprawdzie z krytyczną oceną w Europie, jednak w opiniach klinicystów niemieckich zawierały w sobie elementy racjonalne. $\mathrm{W}$ ujęciu trójbiegunowym pierwsze $\mathrm{z}$ tych koncepcji byłyby klasyfikowane jako nienaukowe, drugie jako przednaukowe (mimo ogólnie nieracjonalnej struktury zawierały bowiem elementy słuszne, które były kontynuowane po 1850 r.) oraz naukowe. Ten status przyznawano koncepcjom blisko spokrewnionym z głównym nurtem europejskiej medycyny klinicznej z lat 1750-1850. Pionierami omawianej orientacji w niemieckiej historiografii medycyny byli nowocześni i wpływowi klinicyści, których poglądy wywierały w latach 1850-1880 dominujący wpływ na kształtowanie się niemieckiego standardu medycyny akademickiej: Rudolf Virchow i Carl August Wunderlich. Virchow odrzucał całościową negatywną ocenę niemieckiej medycyny romantycznej jako wstecznej i opartej na błędnym standardzie epoki w dziejach rodzimej medycyny. Uważał, że tworzony w latach 1797-1848 w medycynie niemieckiej standard interpretacyjny nie był standardem epigonalnym wobec standardu nauki europejskiej, ale próbą rozwiązania stających przez medycyną kliniczną w pierwszej połowie XIX w. problemów teoretycznych i praktycznych w samodzielny sposób. Podejmował swoje badania nad dziejami niemieckiej medycyny, stawiając pytania, kiedy i w jaki sposób w epoce (tj. w okresie niemieckiej medycyny romantycznej), w której obowiązujący na uniwersytetach standard medycyny nie jest oparty na racjonalnych podstawach, zrodziły się zaczątki koncepcji, które są po $1850 \mathrm{r}$. kontynuowane i obecnie uznawane za racjonalne. Nowe zdefiniowanie przedmiotu badań historiografii pozwoliło Virchowowi na wyróżnienie wśród oryginalnych niemieckich szkół naukowych z lat 1797-1848 sprzecznych ze standardem ogólnoeuropejskim tych spośród nich, których poszukiwania teoretyczne nie mogą być po $1850 \mathrm{r}$. odrzucone. Odznaczają się bowiem samoistną wartością naukową (są więc zaliczane do grupy koncepcji naukowych, a nie nienaukowych lub przednaukowych), mimo że ich standard nie był poza Niemcami akceptowany ${ }^{79}$. Do tego rodzaju szkół Virchow zaliczał przede wszystkim szkołę Johanna Lucasa Schönleina, którą uznawał za innowacyjną w kontekście europejskim, a także szkołę Philippa Franza

79 Por. R. Virchow, Die naturwissenschaftliche Methode und die Standpunkte in der Therapie, „Virchows Archiv für pathologische Anatomie und wissenschaftliche Medizin” 2, 1849, s. 3-37. 
von Walthera ${ }^{80}$. Podobne podejście do dziejów rodzimej medycyny w pierwszej połowie XIX w. spotykamy u innego niemieckiego klinicysty - Carla Augusta Wunderlicha. W pracach $\mathrm{z}$ lat $1841^{81}$ (a więc jeszcze $\mathrm{z}$ okresu obowiązywania standardu niemieckiej medycyny romantycznej) i $1858^{82}$ (wydanej już po usunięciu tego standardu $\mathrm{z}$ uniwersytetów w Niemczech) wyraźnie stwierdzał, że w niemieckiej medycynie klinicznej pierwszej połowy XIX w. tkwi samoistna i innowacyjna wartość. Wunderlich uważał, że postęp w medycynie klinicznej nie jest równoznaczny z zaakceptowaniem we wszystkich krajach Europy metodologicznego standardu medycyny francuskiej, który uznawał - jak większość dziewiętnastowiecznych autorów niemieckich - za niemożliwy do zaakceptowania ze względów światopoglądowych i teoretycznych. Zdaniem Wunderlicha, celem uprawiania historiografii medycyny nie powinno być - jak u współczesnego mu Haesera - dążenie do wyczerpującego opisu faktów dotyczących dziejów medycyny dawnych epok i przedstawianie ich historycznego komentarza. Stawiał historykom medycyny inne cele: dążenie do ukazania dróg wiodących do standardu, który uznajemy za naukowy współcześnie. Zgodnie $\mathrm{z}$ tym zamysłem nie jest istotne odtwarzanie w kompletnym kształcie wiedzy medycznej oraz poglądów szkół naukowych $\mathrm{z}$ dawnych epok, ale poszukiwanie w nich śladów koncepcji, które były następnie w medycynie rozwijane i są współcześnie uznawane za racjonalne. Tego rodzaju ujęcie pozwalało wydobyć z dorobku niemieckiej medycyny klinicznej z pierwszej połowy XIX w. realne osiągnięcia naukowe, pozbawiając je otaczającego kontekstu. Możliwe było np. ukazanie pionierskich poglądów Friedricha Gustava Jacoba Henlego jako prekursora bakteriologii (bez wzmianki o tym, że $\mathrm{w}$ momencie ich publicznego przedstawienia spotkały się ze zmasowaną krytyką w niemieckim środowisku akademickim) albo Jana Evangelisty Purkyniego jako pioniera późniejszego standardu fizjologii (bez wspominania, że w czasach jego naukowej działalności jego poglądy nie były szerzej popularyzowane, a w niemieckiej medycynie akademickiej dominowały koncepcje romantyczne stworzone przez C.G. Carusa i K.F. Burdacha).

Przykładem interpretacji trójbiegunowej jest także podręcznik autorstwa Juliusa Petersena ${ }^{83}$, który śledzi w strukturze medycyny niemieckiej rywalizację trzech nurtów, stanowiących odzwierciedlenie wpływów trzech kolejnych faz w historii europejskiej medycyny: teokratycznej, filozoficznej i naukowej, którą uważał za wolną od wpływów filozofii i religii, a więc już w pełni profesjonalną. Jest to jedna z pierwszych prac opublikowanych poza Niemcami, w których zawarte są

${ }^{80}$ Por. tenże, Gedächtnisrede auf Johann Lucas Schönlein, Berlin 1865.

${ }^{81}$ Por. C.A. Wunderlich, Wien und Paris. Ein Beitrag zur Geschichte und Beurteilung der gegenwärtigen Heilkunde in Deutschland und Frankreich, Leipzig 1841.

${ }_{82}$ Por. tenże, Geschichte der Medizin, Stuttgart 1858.

${ }^{83}$ Por. J. Petersen, Hauptmomente in der geschichtlichen Entwicklung der Medizinischen Therapie, Kopengahen 1877. 
szersze wzmianki o niemieckiej medycynie romantycznej. W przeciwieństwie do wspomnianych wyżej autorów niemieckich, Virchowa i Wunderlicha, Petersen - publikujący swoją książkę w Danii - stosuje w opisie medycyny niemieckiej z pierwszej połowy XIX w. podział trójbiegunowy, oceniając cały ten okres skrajnie krytycznie i nie odnajdując w nim żadnych przejawów innowacyjności. Petersen stwierdzał, że zwolennicy standardu romantycznego odgrywali rolę hamującą postęp w medycynie niemieckiej, aprobując koncepcje w innych krajach dawno już uznane za anachroniczne i usunięte poza granice profesjonalnego dyskursu klinicznego. Autor wyróżnia wśród nich koncepcje zupełnie niezgodne $\mathrm{z}$ akademickim europejskim standardem racjonalności (a więc nienaukowe) oraz te, które były w Europie akceptowane, ale w XVI i XVII w., przed ukształtowaniem się standardu głównego nurtu medycyny klinicznej (połowa XVIII w.). Zalicza więc te koncepcje do przednaukowych. W ujęciu Petersena do fazy naukowej w niemieckiej medycynie klinicznej pierwszej połowy XIX w. należą jedynie ci lekarze kliniczni, którzy przyjęli i zaakceptowali współczesny im europejski standard kliniczny.

Na przełomie XIX i XX w., a więc niemal pół wieku po dyskredytacji standardu niemieckiej medycyny romantycznej i usunięciu go z dydaktyki uniwersyteckiej, opadły już emocje związane z oceną tej epoki. Do wzrostu liczby poświęconych jej problematyce publikacji przyczyniły się dwa fakty. Pierwszym z nich było zjednoczenie Niemiec, którego następstwem okazała się patriotyczna euforia niektórych historyków medycyny, pragnących zdjąć odium nienaukowości z rodzimej tradycji medycznej pierwszej połowy XIX stulecia i odszukać w niej elementy i postacie, których dokonania z perspektywy czasu okazały się wartościowe. Drugim czynnikiem w genezie wzrostu zainteresowania standardem niemieckiej medycyny romantycznej wśród autorów niemieckich było powszechne przyjęcie w medycynie europejskiej po $1880 \mathrm{r}$. standardu bakteriologii, które doprowadziło do zmiany w podstawowych poglądach dotyczących patologii i klasyfikacji chorób. W związku z tym wszystkie koncepcje patologii nieuwzględniające roli bakterii w etiologii chorób uznać trzeba było za błędne, niezależnie od różnic pomiędzy nimi oraz rodzaju metodologii, na której się opierały. Konstatacja ta stała się podłożem dla stworzenia w niemieckiej historiografii medycyny nowych klasyfikacji okresu 1797-1848, określanych mianem wielobiegunowych. Prace historyków medycyny zbliżyły się do źródeł, nie nakładając na nie apriorycznych interpretacji, których przykładem był podział dwubiegunowy lub trójbiegunowy, ale próbowały wyróżnić w niemieckiej medycynie klinicznej postacie wpływowych klinicystów z pierwszej połowy XIX w., opisać ich poglądy, zbadać założone przez nich szkoły itp. Wielobiegunowa interpretacja fenomenu niemieckiej medycyny romantycznej stopniowo zaczęła zatracać wcześniej obecne w niemieckiej historiografii medycyny dotyczącej okresu 1797-1848 silne, negatywne wartościowanie. Stało się tak dlatego, że wprawdzie historia medycyny nadal była obowiązkowym przedmiotem w programie nauczania na studiach medycznych, jednak - w związku z postępem 
w naukach podstawowych oraz w medycynie praktycznej - przedstawiane studentom koncepcje z pierwszej połowy XIX w. nie były już przez lekarzy z końca XIX i pierwszych dwóch dekad XX w. w żaden sposób wykorzystywane praktycznie. Były omawiane jedynie dla wzbogacenia erudycji studentów, a nie ich doświadczenia klinicznego (co w początkach XIX w. było impulsem do wprowadzenia historii medycyny jako przedmiotu obowiązkowego w kształceniu przyszłych lekarzy). Zmiana rangi historii medycyny oznaczała „muzealizację" tego przedmiotu oraz postępującą profesjonalizację standardu metodologicznego, zgodnie z którym tworzona była historiografia medycyny. Wprawdzie aż do lat 70. XX w. kierownikami zdecydowanej większości instytutów i katedr historii medycyny nadal byli w Europie i USA lekarze, jednakże w końcu XIX w. zaczęło się stopniowe zbliżanie standardu niemieckiej historiografii medycyny do standardu dyscyplin humanistycznych. Powstałe w Niemczech w początkach XX w. instytuty historii medycyny i nauk przyrodniczych w Lipsku, Berlinie, Freiburgu i wielu innych miastach prowadzić zaczęly praktykę naukową na wzór ówczesnych niemieckich instytutów historii. Zajmowali się nią nadal wprawdzie wyłącznie lekarze, jednakże ich działalność była już oddzielona od dydaktyki klinicznej. Utraciła więc w związku z tym swoje bezpośrednie znaczenie propedeutyczne, wynikające $\mathrm{z}$ dostarczania studentom medycyny wiedzy o faktach klinicznych i omawiania ich dawnych interpretacji, na rzecz oddziaływań pośrednich: kształtowania ogólnego etosu zawodowego lekarza i podstaw jego światopoglądu. Praca niemieckich historyków medycyny do $1945 \mathrm{r}$. zbliżyła się pod względem warsztatowym do praktyki historyków. Akademickie instytuty historii medycyny drogą zakupów i darowizn zgromadziły potężną bazę źródłową dotyczącą historii rodzimej medycyny z XIX w., co doprowadziło do pojawienia się kolejnych teoretycznych konceptualizacji dotyczących fenomenu niemieckiej medycyny romantycznej ${ }^{84}$.

Pierwszą z nich była tzw. szkoła neoromantyczna, do której koryfeuszy należeli Paul Diepgen ${ }^{85}$ na Uniwersytecie w Berlinie i Werner Leibbrand ${ }^{86}$ na Uniwersytecie we Freiburgu ${ }^{87}$. Była to szkoła o ukierunkowaniu antypozytywistycznym

84 Przykłady piśmiennictwa historycznomedycznego z lat 1880-1945 dotyczące epoki 1797-

-1848 przedstawiam w monografii pt. Niemiecka medycyna niematerialistyczna..., s. 29-45.

${ }^{85}$ Por. P. Diepgen, Deutsche Medizin vor hundert Jahren: ein Beitrag zur Geschichte der Romantik, Freiburg am Breisegau 1923. Prace tego autora dotyczące tego okresu omawiam w pracach przedstawionych w przyp. 87.

${ }^{86}$ Por. W. Leibbrand, Romantische Medizin, Leipzig 1937. Prace tego autora dotyczące niemieckiej medycyny romantycznej omawiam w pracach przedstawionych w przyp. 87.

${ }^{87}$ Por. B. Płonka-Syroka, Pojęcie stylu myślowego u Ludwika Flecka, Paula Diepgena $i$ Wernera Leibbranda i konsekwencje jego wykorzystania w praktyce badawczej historyka medycyny, w: Proces modernizacji nauk przyrodniczych $w$ historii i historiografii nauki, red. B. Płonka-Syroka, Wrocław 2003 (Studia z Dziejów Kultury Medycznej, 7), s. 228-239; taż, Proces modernizacji nauk medycznych $w$ ujęciu Wernera Leibbranda - przedstawiciela nurtu neoromantycznego $w$ niemieckiej historiografii medycyny pierwszej połowy XX wieku, w: tamże, s. 240-249. 
w zakresie podstaw metodologii, a także nastawiona afirmatywnie do rodzimej tradycji medycznej. Obraz niemieckiej medycyny romantycznej w pracach autorów związanych ze standardem tej szkoły, ukazujących się do drugiej połowy lat 50. XX w., był pozytywny. Autorzy należący do tego nurtu w historiografii odrzucali jej charakterystykę jako epoki epigonalnej wobec głównego nurtu europejskiej medycyny klinicznej. Podkreślali nowatorstwo metodologiczne niemieckich klinicystów i prekursorstwo niektórych ze stworzonych przez nich koncepcji wobec standardu medycyny z pierwszej połowy XX w. Pozytywnie oceniali rodzime teorie, doktryny i związane $\mathrm{z}$ ich upowszechnianiem szkoły naukowe, powstające w opozycji do głównego nurtu medycyny klinicznej w Europie. W interpretacjach epoki romantycznej tworzonych przez związanych $\mathrm{z}$ tą szkołą autorów występowało ujęcie dwubiegunowe, przeciwstawiające rodzimą niemiecką myśl medyczną, której przypisywano wysoki poziom i nowatorstwo, myśli europejskiej skupionej w głównym nurcie klinicznym, którą oceniano krytycznie. Podstawą tej krytyki były takie cechy, które przypisywano medycynie klinicznej głównego nurtu, jak jednostronność, chwiejność teoretyczna, oparcie na niewłaściwych podstawach filozoficznych itp. Powtarzano więc $w$ dużej mierze argumenty niemieckich romantyków medycznych wysuwane sto lat wcześniej przeciw europejskim klinicystom, nadal uznając je za zasadne.

W okresie międzywojennym powstała także w Niemczech inna szkoła historiograficzna o ukierunkowaniu antypozytywistycznym, prowadząca badania nad historią rodzimej medycyny. Była to szkoła Karla Sudhoffa ${ }^{88}$, stworzona na Uniwersytecie w Lipsku. Wypracowany w niej standard metodologiczny w szerokim zakresie uwzględniał wpływ czynników zewnątrznaukowych na genezę teorii i doktryn medycznych, zakorzeniając je w otaczającym środowisku kulturowym. Szkoła Kulturgeschichte der Medizin opierała swoje publikacje na szczegółowych badaniach źródłowych, zmierzając do unikania apriorycznych klasyfikacji oraz wniosków podporządkowanych $\mathrm{z}$ góry założonym tezom (np. o rywalizacji w medycynie niemieckiej dwóch nurtów, wstecznego i postępowego). Kulturaliści rozwinęli z czasem swój standard badań w stronę Sozialgeschichte der Medizin, uwzględniając w genezie teorii i doktryn medycznych obok czynników kulturowych także realnie występujące problemy społeczne, uznawane przez lekarzy za warte rozwiązania lub do rozwiązania możliwe przy aktualnym stanie wiedzy. Pionierem tego nurtu był Henry E. Sigerist ${ }^{89}$. Nacisk kładziony przez kulturalistów na opis tworzenia się systemów wiedzy medycznej zgodnie ze strzałką czasu powodował, że zarzucili typowy dla prac klinicznych schemat narracyjny, występujący we wcześniejszej historiografii. Opierał się on na trzech stopniach: 1) określeniu stanu

${ }^{88}$ Por. K. Sudhoff, Th. Meyer-Steineg, Geschichte der Medizin in Überblick, Leipzig 1922.

89 Por. Henry Ernst Sigerist (1891-1957). Begründer einer modernen Sozialgeschichte der Medizin. Ausgewählte Texte, red. A. Thom, K.-H. Karbe, Leipzig 1981. 
rzeczy $\mathrm{w}$ danej kwestii, zgodnego $\mathrm{z}$ aktualnym stanem badań; 2) określeniu, kto, kiedy i w jakim stopniu dostrzegł ten stan rzeczy po raz pierwszy; 3) śledzeniu w piśmiennictwie naukowym kolejnych „odsłon” zbliżających lekarzy do prawdziwego oglądu poznawanego fragmentu rzeczywistości. Zastąpili go typowym schematem historycznym, opartym na następujących etapach: 1) określeniu, jak wyglądało $\mathrm{w}$ danej epoce postrzeganie problemów medycznych uznawanych za realne i wymagających według lekarzy jakiegoś rozwiązania; 2) określeniu, w jaki sposób problemy te były konceptualizowane i jak je rozwiązywano; 3) określeniu, jakie osiągano rezultaty.

Członkowie szkoły kulturalistycznej w swoich opracowaniach dotyczących niemieckiej medycyny romantycznej kontynuowali wypracowane $\mathrm{w}$ drugiej połowie XIX w. ujęcie wielobiegunowe ${ }^{90}$. Uwypuklali panującą w piśmiennictwie lekarskim różnorodność, analizowali kryteria racjonalności naukowej, na których ich autorzy się opierali, nie narzucając z góry oceny ich poglądów jako irracjonalnych. Wypracowany w szkole kulturalistycznej standard metodologiczny rozprzestrzenił się po 1933 r. w amerykańskiej i angielskiej historiografii medycyny, ponieważ związani $\mathrm{z}$ instytutem lipskim uczeni zostali ze względu na swoje pochodzenie zmuszeni do emigracji. Po 1945 r. standard kulturalistyczny ponownie odzyskał wpływy w Niemczech, wypierając interpretacje neoromantyczne. Zgodnie z jego założeniami metodologicznymi powstały w Niemczech do 1970 r. tysiące publikacji poświęconych wybranym przedstawicielom medycyny niemieckiej z lat 1797-1848. W efekcie prawie każdy niemiecki lekarz, który pozostawił w pierwszej połowie XIX w. jakiś ślad w literaturze specjalistycznej swego czasu, posiada obecnie w niemieckiej historiografii medycyny biografię, dorobek wielu $\mathrm{z}$ nich jest starannie opracowany pod względem bibliograficznym, a najcenniejsze z punktu widzenia naukowego dzieła zostały opublikowane w wydaniach krytycznych. Rezultatem tego procesu stało się wkroczenie niemieckiej historiografii medycyny w nowy etap, co miało miejsce w latach 70 . XX w.

Za jego wyróżnieniem w piśmiennictwie przemawiają nowe cele stawiane historiografii medycyny po 1970 r. ${ }^{91}$ Po okresie rozpoznania źródeł, ich opracowania i publikacji wydań krytycznych podstawowego niemieckiego dorobku

90 Publikacje charakterystyczne dla omawianego nurtu, powstałe zarówno w Niemczech, jak i po wyemigrowaniu po 1933 r. założycieli i członków lipskiej szkoły kulturalistycznej do USA i Wielkiej Brytanii, a także ich kontynuatorów przedstawiam w monografii pt. Medycyna w historii i kulturze... (2016), s. 28-34, 117-128.

91 Por. publikacje programowe autorstwa Dietricha von Engelhardta ( $Z u$ einer Sozialgeschichte der romantischen Naturforschung, „Sudhoff's Archiv für Geschichte der Medizin” 63, 1981, z. 3, s. 209-225) i Roberta Jüttego (Sozialgeschichte der Medizin: zakres - metody - cele, tłum. T. Srogosz, „Medycyna Nowożytna. Studia nad Kulturą Medyczną” 7, 2000, z. 1, s. 25-42). Piśmiennictwo dotyczące niemieckiej medycyny romantycznej utrzymane w nowym standardzie metodologicznym omawiam w monografiach: Niemiecka medycyna romantyczna... (2007), s. 57-120; Medycyna w historii i kulturze... (2016), s. 135-142. 
naukowego $\mathrm{z}$ okresu niemieckiej medycyny romantycznej, nastąpił okres badań porównawczych, tworzenia opracowań syntetycznych, badań interdyscyplinarnych oraz wprowadzających do historiografii medycyny nową teoretyczną perspektywę - Alltagsgeschichte, a następnie tzw. Patient's View. Najważniejszą innowacją w nowym standardzie historiografii była jednak zmiana sposobu określania granic historiografii medycyny jako dyscypliny naukowej. Od jej powstania w początkach XIX w. do lat 70. XX w. była ona historią profesjonalnego dyskursu, wytwarzanego przez lekarzy i kierowanego do innych przedstawicieli tej profesji. Wszystkie czynniki występujące w pracach historycznomedycznych miały charakter dodatkowy. W latach 70. dokonała się zmiana perspektywy - uznano medycynę za jeden $z$ charakterystycznych dla danej epoki sposobów postrzegania i opisu otaczającego świata. Zainicjowano więc badania porównawcze nad tymi kwestiami, zarówno w ujęciu diachronicznym, jak i synchronicznym. Tworzono publikacje, w których nie tylko (jak dawniej) lekarze w pewien sposób patrzyli na pacjentów, ale także pacjenci ( $\mathrm{z}$ własnej perspektywy) postrzegali lekarzy. W latach 80 . XX w. to nowe ujęcie metodologiczne szybko zaczęło się upowszechniać w niemieckiej historiografii medycyny, a od lat 90. do chwili obecnej jest ujęciem dominującym.

$\mathrm{W}$ omawianym tu standardzie interpretacyjnym powstało w ostatnich czterech dekadach kilka tysięcy prac poświęconych niemieckiej medycynie romantycznej. Ich wspólną cechą jest podjęcie polemiki z historykami medycyny z drugiej połowy XIX w., ukazującymi standard niemieckiej medycyny klinicznej z lat 1797-1848 jako względnie jednolity, funkcjonujący w trwałej opozycji wobec głównego nurtu medycyny europejskiej, a następnie, tj. po 1849 r., nieznajdujący kontynuacji. Wszystkie te tezy zostały przez nową niemiecką historiografię zakwestionowane w oparciu o analizy źródeł z epoki. Wykazano także, że realny zasięg oddziaływania narzucanego przez władze antyempirycznego standardu romantycznego był relatywnie mniejszy, niż to wcześniej stwierdzano, głównie na podstawie analizy podręczników oraz publikacji tworzonych przez członków niemieckiego środowiska akademickiego, aprobujących założenia standardu romantycznego. Szczegółowa analiza tysięcy publikacji wydanych w latach $1797-1848$ przez lekarzy niemieckich, w tym niezwiązanych ze środowiskiem akademickim, przede wszystkim prac kazuistycznych, wskazuje bowiem nie tylko na znajomość europejskiego standardu klinicznego wyrażaną przez ich autorów, lecz także na jego aprobatę i stosowanie się przez nich w praktyce do zgodnych z tym standardem reguł metodologicznych. Podkreśla się także istniejące rozbieżności między niemieckimi szkołami klinicznymi z lat 1797-1848, tworzące obraz pluralizmu teoretycznego i terapeutycznego. Analizuje się wypracowywane przez lekarzy niemieckich sposoby dochodzenia do prawdy, ich koncepcje epistemologiczne i antropologiczne. Nie wszystkie z nich można bowiem określić jako przykłady prostej recepcji poglądów rodzimych filozofów (głównie Kanta, Schellinga oraz Hegla), występowały w nich bowiem liczne oryginalne pomysły, warte naukowych analiz. 
Ukształtowany po 1970 r. i dominujący po 1990 r. w światowej historiografii medycyny romantycznej obraz niemieckiej medycyny romantycznej umieszcza tę epokę w szerszym kontekście europejskim. W różnych krajach Europy badane są różne konceptualizacje problemów wymagających rozwiązania, a także sposoby ich rozwiązywania przez lekarzy. Badane są relacje lekarzy z władzami państw europejskich oraz przedstawicielami instytucji kościelnych. Wyciągane na podstawie analiz obszernego materiału źródłowego wnioski utraciły w nowym standardzie piśmiennictwa walor propedeutyczno-formacyjny, uznawany wcześniej za podstawowy cel istnienia akademickiej historiografii medycyny. Nowe piśmiennictwo historycznomedyczne stawia przed sobą przede wszystkim cele poznawcze, nie jest już pisane głównie przez lekarzy dla lekarzy i studentów medycyny. Autorami większości prac są bowiem humaniści lub lekarze dysponujący dużą erudycją w metodologii badań humanistycznych, a odbiorcami publikacji podejmujących problematykę historii medycyny są - obok historyków - także przedstawiciele innych dyscyplin humanistycznych prowadzący badania nad historią zdrowia i choroby, a także wykształcona publiczność, pragnąca zapoznać się $\mathrm{z}$ tą problematyką.

Ponieważ współczesny standard kliniczny (Evidence Based Medicine) nie jest we współczesnej nauce kwestionowany, a jest on kontynuacją perspektywy poznawczej wypracowanej w okresie tzw. medycznego oświecenia, współczesne prace historycznomedyczne nie podejmują się rewaloryzacji poglądów niemieckich romantyków medycznych w celu wykazania ich racji w sporze z klinicystami głównego nurtu, zarówno w XIX stuleciu, jak i współcześnie. Jednakże w związku ze zmianą metodologicznej perspektywy w nowej historiografii medycyny tworzonej po $1970 \mathrm{r}$. w analizie poglądów lekarzy niemieckich z pierwszej połowy XIX w. pojawiło się nowe pytanie: co spowodowało, że zespół poglądów charakterystyczny dla standardu niemieckiej medycyny romantycznej uznali oni w pewnym okresie za racjonalny, i to mimo tego, że w europejskiej społeczności klinicystów było to w latach 1797-1848 stanowisko odosobnione? Czy była to decyzja ugruntowana $\mathrm{w}$ ich głęboko zakorzenionych poglądach z zakresu metodologii medycyny, jej filozofii oraz podstaw antropologicznych, czy też należy ją rozpatrywać raczej jako wynik konformistycznej odpowiedzi na wyraźnie precyzowane oczekiwania władzy wobec środowiska akademickiego? Nie bada się już fenomenu niemieckiego romantyzmu medycznego, zakładając z góry, że wytworzony przez jego twórców standard uznać należy w świetle Evidence Based Medicine za błędny. Jest to bowiem sprawa oczywista. Pytanie brzmi inaczej: dlaczego lekarze tworzący $\mathrm{w}$ epoce niemieckiego romantyzmu medycznego wybierali te, a nie inne argumenty na rzecz odmiennego niż europejski standardu, jak przebiegało ich rozumowanie, jakie były skutki teoretyczne i praktyczne dokonanych przez nich 
wyborów, jak można porównać efektywność medycyny niemieckiej przed $1848 \mathrm{r}$. z medycyną europejską, jakie były przesłanki ostatecznego odrzucenia standardu romantycznego w Niemczech, tj. dlaczego władze państwowe uznały go za niemożliwy do dalszego podtrzymywania na uniwersytetach oraz na podstawie jakich argumentów został ostatecznie uznany za błędny przez zdecydowaną większość niemieckich lekarzy. Pytania tego rodzaju inspirują tworzenie dalszych heurystyk, umożliwiających analizę wybranych problemów naukowych.

Niemiecka medycyna romantyczna $\mathrm{z}$ lat 1797-1848 stała się także w drugiej połowie XX w., a szczególnie od lat 70. tego stulecia, przedmiotem badań historyków medycyny $z$ innych krajów europejskich oraz z USA. W genezie zainteresowania tym problemem możemy wyróżnić następujące elementy. 1) Pojawienie się po 1933 i po 1945 r. w USA, Wielkiej Brytanii, Nowej Zelandii i Australii emigrantów z Niemiec, w tym lekarzy, którzy pragnęli uzyskać w tych krajach stopnie doktora nauk medycznych. Znając biegle język niemiecki, podejmowali badania nad niemiecką tradycją medyczną, mając łatwy dostęp do wydawanych w tym języku źródeł. 2) Pojawienie się w USA i Wielkiej Brytanii po 1933 r. emigrantów z Niemiec, obejmujących stanowiska kierowników instytutów historii medycyny i aplikujących w tych krajach nie tylko nowy, antypozytywistyczny standard interpretacyjny, lecz także tematykę badań związaną z historią nauki niemieckiej. Ich wychowankowie doprowadzili do transformacji amerykańskich i angielskich instytutów historii medycyny w placówki prowadzące badania w standardzie zbliżonym do nauk humanistycznych, w którym medycyna jest umieszczana w szerszym kontekście kulturowym i społecznym. 3) Pojawienie się w latach 60. XX w. metodologii historii nauki koncepcji Thomasa Samuela Kuhna, która w latach 60. i 70. zdobyła światową popularność w historiografii medycyny. Inspirowane koncepcją Kuhna prace historycznomedyczne podejmowały tematykę uznawaną wcześniej przez historyków medycyny za niewartą badań $\mathrm{i}$ analiz, a której eksploracja była możliwa $\mathrm{z}$ uwagi na bardzo dużą liczbę zupełnie niewykorzystanych źródeł. 4) Pojawienie się w latach 70. porównawczej historiografii medycyny, zainteresowanej odtworzeniem możliwie szerokiej panoramy dziejów nauk przyrodniczych, uwzględniającej także i te koncepcje naukowe, które nie przeszły próby czasu. 5) Pojawienie się w latach 80 . socjologii medycyny, a w kolejnej dekadzie antropologii medycyny klinicznej. Przedstawiciele tych nauk podjęli współpracę z historykami medycyny, wykazując duże zainteresowanie dla różnego rodzaju form świadomości naukowej, odległych od głównego nurtu klinicznego.

Wszystkie te czynniki powodują utrwalenie się zainteresowania badaczy fenomenem niemieckiej medycyny romantycznej, który jest tematem rosnącej liczby publikacji. Sprzyja temu zainteresowaniu obfitość źródeł, ich bardzo dobra ewidencja i względnie latwy dostęp. W okresie niemieckiej medycyny romantycznej funkcjonowało bowiem w Niemczech prawie sto uniwersytetów, 
których przedstawiciele podejmowali się rozwiązania aktualnych w tym czasie kwestii medycznych. Ponieważ koryfeusze medycyny tej epoki zostali już dobrze opisani w monografiach, dominującą obecnie tendencją w historiografii tej epoki są analizy dorobku mniej znaczących postaci. Dorobek ten z pewnością na to zasługuje, a jego analiza przyczynia się stopniowo do destrukcji czarnej legendy niemieckiego romantyzmu medycznego, nie tylko w rodzimej, lecz także i w światowej historiografii. Nowa historiografia tego okresu przekreśla możliwości jego charakterystyki w kategoriach występujących wcześniej w syntezach, stosujących ujęcie jedno-, dwu-, a nawet trójbiegunowe. Za najbardziej zasadne uznaje się obecnie ujęcie wielobiegunowe, podkreślające nie tylko różnorodność teoretyczną badanej epoki wewnątrz jej własnego standardu, lecz także spójność i rozłączność $\mathrm{z}$ wybranymi elementami europejskiego standardu klinicznego. W ten sposób kwestia niemieckiej medycyny romantycznej stała się przedmiotem uwagi już nie tylko niemieckich historyków medycyny, lecz także przedstawicieli innych historiografii europejskich, zainteresowanych odmiennością jej standardu, ale i jego powiązaniem z medycyną europejską tej epoki, którego mimo wysiłków cenzury i obsadzania stanowisk akademickich przez osoby spolegliwe wobec władzy nie udało się ani zahamować, ani też uniknąć jego skutków, zarówno w teorii, jak i w praktyce.

\section{Bibliografia}

P. Badyna, Bóg i przyroda w XVIII-wiecznym piśmiennictwie przyrodoznawczym jako konstrukt kulturowy, w: Obrazy świata jako konstrukty świata kultury. Analiza historyczno-porównawcza, red. B. Płonka-Syroka, A. Syroka, Wrocław 2012 (Studia z Dziejów Kultury Medycznej, 12), s. 15-34

M. Boas-Hall, Promoting Experimental Learning. Experiment and the Royal Society (1660-1727), New York 1991

F.T. Brechka, Gerhard van Swieten and his World 1700-1772, Hague 1970

F.C. Breiser, Enlightenment, Revolution und Romanticism. The Genesis of Modern German Political Thought 1790-1800, Cambridge (Mass.) 1992

G. Buchholz, Die Medizintheorie Claude Bernard's: ihr philosophischer und wissenschaftlicher Hintergrund, Murken 1985

P. Chaunu, Cywilizacja wieku Oświecenia, tłum. E. Bąkowska, Warszawa 1993

F. Cohen, Die zweite Erschaffung der Welt. Wie die moderne Naturwissenschaft entstand, Frankfurt-New York 2010

A. Croce-Birch, The Problem of Method in Newton's Natural Philosophy, w: Nature and Scientific Method, red. D.D. Dahlstrom, Washington 1991, s. 253-270

A. Cunningham, R. French, The Medical Enlightenment of the Eighteenth Century, Cambridge 1990

D. von Engelhardt, Zu einer Sozialgeschichte der romantischen Naturforschung, „Sudhoff's Archiv für Geschichte der Medizin” 63, 1981, z. 3, s. 209-225

D. Golz, Naturmystik und Naturwissenschaft in der Medizin um 1600, „Sudhoff's Archiv für Geschichte der Medizin und der Naturwissenschaften” 60, 1976, z. 1, s. 54-65

M. Hahn, H.J. Sandkühler, Die Teilung der Vernunft. Philosophie und empirisches Wissen im 18. und 19. Jahrhundert, Köln 1982 
Henry Ernst Sigerist (1891-1957). Begründer einer modernen Sozialgeschichte der Medizin. Ausgewählte Texte, red. A. Thom, K.-H. Karbe, Leipzig 1981

V. Hess, Von der semiotischen zur diagnostischen Medizin. Die Entstehung der klinischen Methode zwischen 1750 und 1850, Husum 1993

C. Huercamp, Der Aufstieg der Ärzte im 19. Jahrhundert. Vom gelehrten Stand zum professionellen Experten. Das Beispiel Preussen, Göttingen 1985

R. Jütte, Sozialgeschichte der Medizin: zakres - metody - cele, tłum. T. Srogosz, „Medycyna Nowożytna. Studia nad Kulturą Medyczną" 7, 2000, z. 1, s. 25-42

L.S. King, The Medical World of the Eighteenth Century, Chicago 1958

L.S. King, The Philosophy of Medicine. The Early Eighteenth Century, Cambridge (Mass.)-London 1978

H. Koelbing, Die ärztliche Therapie. Grundlage ihrer Geschichte, Darmstadt 1985

Z. Kuderowicz, Filozofia nowożytnej Europy, Warszawa 1980

E. Lesky, Wien und die Weltmedizin, Wien-Köln 1974

Medical Theory and Therapeutic Practice in the Eighteenth Century. A Transatlantic Perspective, red. J. Helm, R. Wilson, Stuttgart 2008

Medicine and the Reformation, red. O.P. Grell, London 1993

L. Miodoński, Całość jako paradygmat rozumienia świata w myśli niemieckiej przełomu romantycznego. Analiza wybranych problemów, Wrocław 2001

Paracelsus. Mikrokosmos und Makrokosmos: okkulte Schriften, red. H. Werner, München 1989

K. Pfeifer, Medizin der Goethezeit. Christoph Wilhelm Hufeland und die Heilkunst des 18. Jahrhunderts, Köln-Weimar-Wien 2000

B. Płonka-Syroka, Imputacje kulturowe $w$ standardzie niemieckiej medycyny romantycznej, w: Antropologia medycyny i farmacji w kontekście kulturowym, społecznym $i$ historycznym, red. B. Płonka-Syroka, Wrocław 2008 (Studia Humanistyczne Wydziału Farmaceutycznego Akademii Medycznej we Wrocławiu, 1), s. 313-331

B. Płonka-Syroka, Koncepcja podmiotowości człowieka wobec podstawowych pojęć medycyny teoretycznej i praktycznej, „Kwartalnik Historii Nauki i Techniki” 43, 1998, nr 2, s. 65-76

B. Płonka-Syroka, Medycyna czasów Restauracji (1815-1848) na przykładzie medycyny akademickiej we Francji i Prusach, w: Medycyna i religia, t. 2, red. B. Płonka-Syroka, M. Dąsal (w przyg. do druku)

B. Płonka-Syroka, Medycyna kliniczna i alternatywna - próba charakterystyki porównawczej, w: Gra możliwości. Studia z historii medycyny i farmacji XIX i XX wieku, red. B. Płonka-Syroka, Wrocław 2011 (Studia Humanistyczne Wydziału Farmaceutycznego Akademii Medycznej we Wrocławiu, 4), s. 23-42

B. Płonka-Syroka, Medycyna niemiecka nurtu niematerialistycznego 1797-1848 i polska recepcja jej teorii i doktryn $w$ dziewiętnastym stuleciu, Warszawa 1999

B. Płonka-Syroka, Medycyna w historii i kulturze, wyd. 2 rozsz., Warszawa 2016

B. Płonka-Syroka, Mesmeryzm. Od astrologii do bioenergoterapii, wyd. 3 rozsz., Wrocław 2007

B. Płonka-Syroka, Metodologia Ludwika Flecka w kontekście standardu teoretycznego medycyny klinicznej (1750-1850), w: Ludwik Fleck: tradycje, interpretacje, inspiracje, red. B. Płonka-Syroka, P. Jarnicki, B. Balicki, Wrocław 2015, s. 10-40

B. Płonka-Syroka, Niemiecka medycyna romantyczna (1797-1848) w opiniach przedstawicieli polskiego środowiska naukowego do 1863 r., „Wiek XIX. Rocznik Towarzystwa Literackiego im. Adama Mickiewicza" 8(50), 2015, s. 101-119

B. Płonka-Syroka, Niemiecka medycyna romantyczna, Warszawa 2007

B. Płonka-Syroka, Spór o model medycyny klinicznej w Europie (1750-1850): Francja, Austria i Prusy - odmienne warianty modernizacji, w: Zatargi, waśnie, konflikty. W perspektywie historycznej i kulturowej, red. K. Łeńska-Bąk, Opole 2015 (Stromata Anthropologica, 10), s. 163-176 
B. Płonka-Syroka, System policji lekarskiej Johanna Petera Franka jako przykład realizacji oświeceniowej idei prawa do zdrowia, w: Czystość i brud. Higiena nowożytna (XV-XVIII w.), red. W. Korpalska, W. Ślusarczyk, Bydgoszcz 2015, s. 307-328

B. Płonka-Syroka, Wpływ czynników społeczno-politycznych na kształtowanie się systemu medycyny publicznej w Prusach i zjednoczonych Niemczech do 1914 r., w: Czystość i brud. Higiena w XIX wieku. Wokót przełomu bakteriologicznego, red. W. Korpalska, W. Ślusarczyk, Bydgoszcz 2016 (w druku)

Ch. Probst, Der Weg des ärztlichen Erkennens am Krankenbett. Hermann Boerhaave und die Altere Wiener Medizinische Schule (1701-1787), Wiesbaden 1973

Proces modernizacji nauk przyrodniczych $w$ historii $i$ historiografii nauki, red. B. Płonka-Syroka, Wrocław 2003 (Studia z Dziejów Kultury Medycznej, 7)

Revolution und Gegenrevolution 1798-1830: zur geistigen Auseinandersetzung in Frankreich und Deutschland, red. R. Dufraisse, München 1991

U. Schäfer, Physikalische Heilmethoden in den Ersten Wiener Medizinische Schule, Baltimore 1967

M. Stolberg, Therapeutic Pluralism and Conflicting Medical Opinions in the Eighteenth Century. The Patient's View, w: Medical Theory and Therapeutic Practice in the Eighteenth Century. A Transatlantic Perspective, red. J. Helm, R. Wilson, Stuttgart 2008, s. 95-112

N. Tsouyopoulos, Der Einfluss des Neoplatonismus auf die Wissenschaft der Renaissance, „Sudhoff's Archiv für Geschichte der Medizin und der Naturwissenschaften" 60, 1976, z. 1, s. 33-44

E. Weiss, Deutschland und Frankreich um 1800. Aufklärung - Gegenrevolution - Reform, München 1990

William Cullen and the Eighteenth Century Medical World, red. A. Doig, Edinburg 1991

\section{German non-materialistic medicine in 1797-1848 as seen in historiography from 1811-2014}

German non-materialistic medicine arose in opposition to the main modernisation trends in European medicine, known for drawing their inspiration from the philosophy of the Enlightenment. The model of this non-materialistic medicine, referred to in historiography as a 'romantic' one, owed its existence to the efforts of the Prussian authorities who created it in 1797, relying on the assistance of local doctors and philosophers. It was introduced by the administrative order to the medical departments at German universities both in Prussia and in the rest of Protestant Germany. Because the model was at variance with the dominant European standards, its introduction into the University curricula met with opposition from many German doctors - those affiliated with universities and ordinary physicians. However, this opposition failed to affect the position held by the authorities who did not shy away from imposing the norms of scientific rationality on German universities. It was not until the Spring of Nations that this romantic model was removed from German academia. From 1849 onwards the clinical training remained in line with European standards. As the German romantic model - so far removed from the one prevalent at that time in Europe - received so severe a criticism from medical circles, the history of medicine showed no interest in it until the latter half of the twentieth century. Texts devoted to this appeared almost exclusively in German. The purpose of this article is to characterise the phases the historiography of German romantic medicine has undergone since 1811, i.e. since the inception of the professional historiography of German romantic medicine. The author's aim is to highlight the principles that underlay each of the medical models presented in the article and to show the dependence of the way in which the models were evaluated in historiography on the existing medical knowledge. 
Bożena Płonka-Syroka - dr hab., historyk nauki i kultury, a także historiografii nauki. Kierownik Zakładu Humanistycznych Nauk Wydziału Farmaceutycznego Uniwersytetu Medycznego im. Piastów Śląskich we Wrocławiu. Członek Rady Naukowej Instytutu Historii Nauki PAN w Warszawie, a w latach 1992-2015 (z przerwą) pracownik tego Instytutu. Autor 4 książek, redaktor naukowy 10 serii wydawniczych, w ramach których ukazało się ponad 70 tomów, a także autor ok. 200 artykułów i rozdziałów w książkach z zakresu historii medycyny, antropologii medycyny, historii kultury i historii historiografii. E-mail: bozena@plonka-syroka.pl. 